\title{
Paleoproterozoic crust-formation and reworking events in the Tocantins Province, central Brazil: A contribution for Atlantica supercontinent reconstruction
}

\author{
Reinhardt A. Fuck ${ }^{a}$, Elton Luiz Dantas ${ }^{a, *}$, Márcio Martins Pimentel ${ }^{a}$, \\ Nilson Francisquini Botelho ${ }^{a}$, Richard Armstrong ${ }^{c}$, Jorge Henrique Laux ${ }^{\mathrm{b}}$, \\ Sergio Luiz Junges ${ }^{a}$, José Eduardo Soares ${ }^{a}$, Igor Fernandes Praxedes ${ }^{\text {a }}$ \\ a Universidade de Brasília, Instituto de Geociências, Campus Asa Norte, 70910-900 Brasília, DF, Brazil \\ b CPRM - Serviço Geológico do Brasil, Brazil \\ ${ }^{c}$ ANU, Australia
}

\section{A R T I C L E I N F O}

\section{Article history:}

Received 7 March 2013

Received in revised form 2 December 2013

Accepted 6 December 2013

Available online 7 January 2014

Keywords:

Paleoproterozoic supercontinent

Tocantins Province

Crustal evolution

\begin{abstract}
A B S T R A C T
The Natividade-Cavalcanti crustal block is a Paleoproterozoic sialic terrain which forms the basement of sedimentary sequences belonging to the Neoproterozoic Brasília Belt in central Brazil. Two main domains were recognized in this crustal block, the limits of which are not well constrained due to the lack of geological maps at an appropriate scale. The northeastern domain is characterized by narrow supracrustal belts which wrap around gneiss domes. At least three rock-forming events are recorded in the calc-alkaline, metaluminous basement gneisses of this domain: (i) in the Almas-Dianópolis area, granitoids were dated at c. $2.2 \mathrm{Ga}$, (ii) early Paleoproterozoic magmatism was dated at c. $2.3-2.4 \mathrm{Ga}$ in the Natividade-Conceição do Tocantins area, and (iii) younger additions were dated at $2144 \pm 21 \mathrm{Ma}$. $T_{\mathrm{DM}}$ model ages range between 2.24 and $3.11 \mathrm{Ga}$, and $\varepsilon_{\mathrm{Nd}}(t)$ values range from +2 to close to zero, suggesting juvenile sources. Bordering this domain west- and southwards, extending from Cavalcante to Arraias, Paranã and Pindorama do Tocantins, mostly peraluminous granitoids of the Aurumina Suite are exposed. Geochronological data for Aurumina granitoid rocks of this sector point to magmatic events between 2.13 and $2.18 \mathrm{Ga}$, whereas $T_{\mathrm{DM}}$ model ages range between 2.21 and $2.92 \mathrm{Ga}$ with generally negative $\varepsilon_{\mathrm{Nd}}(t)$ values. An exception is a largely undeformed tonalite sample from close to Arraias, dated at $2042 \pm 12 \mathrm{Ma}$.
\end{abstract}

(c) 2014 Elsevier B.V. All rights reserved.

\section{Introduction}

The growth of continental crust during Earth's history has been associated to successive events of juvenile crust formation, followed by periods of landmass stabilization and cratonization, leading to the formation of supercontinents. The accretion and subsequent stabilization events are followed by rifting, breakup and dispersion of the supercontinents, as the result of superplumes, leading to the development of Large Igneous Provinces (LIPs). The concept of Precambrian supercontinents cycles arises, in part, from global peaks of isotopic ages associated with the development of rock associations related to arc systems. Models of crustal growth during the Paleoproterozoic have considered the episodicity of crust formation events at c. 2.0, 1.9 and 1.8 Ga (Condie et al., 2000; Condie, 2002; Reddy and Evans, 2009; Condie and Aster, 2010; Evans and Mitchell, 2011). Several names have been

\footnotetext{
* Corresponding author. Tel.: +55 6131070142 .

E-mail addresses: elton@unb.br, angicos63@gmail.com (E.L. Dantas).
}

suggested for the resulting Paleoproterozoic continental assemblages (Columbia, Atlantica, Nuna; Unrug, 1996; Rogers and Santosh, 2002; Zhao et al., 2006; Evans and Mitchell, 2011). These supercontinents reconstructions are based on craton juxtaposition, using integrated paleomagnetic, geochronologic and geologic data. However, all supercontinents older than Pangaea are conjectural in both existence and paleogeography (Reddy and Evans, 2009). Thus, the identification of large segments of Paleoproterozoic continental crust represents significant contribution to the discussion on supercontinent models.

In this study we describe accretion and reworking events in central Brazil and their significance for the development of supercontinent evolution models. A number of good quality geochronologic data produced over the last years resulted in evidence to support new ideas about the Paleoproterozoic crustal growth in central Brazil. Some of the Rodinia reconstruction models suggest that the Amazonian, Rio de la Plata and São FranciscoCongo continents were still separated from West Africa and other African landmasses at around $1.0 \mathrm{Ga}$ and that their amalgamation process occurred during the Brasiliano-Pan African orogeny 


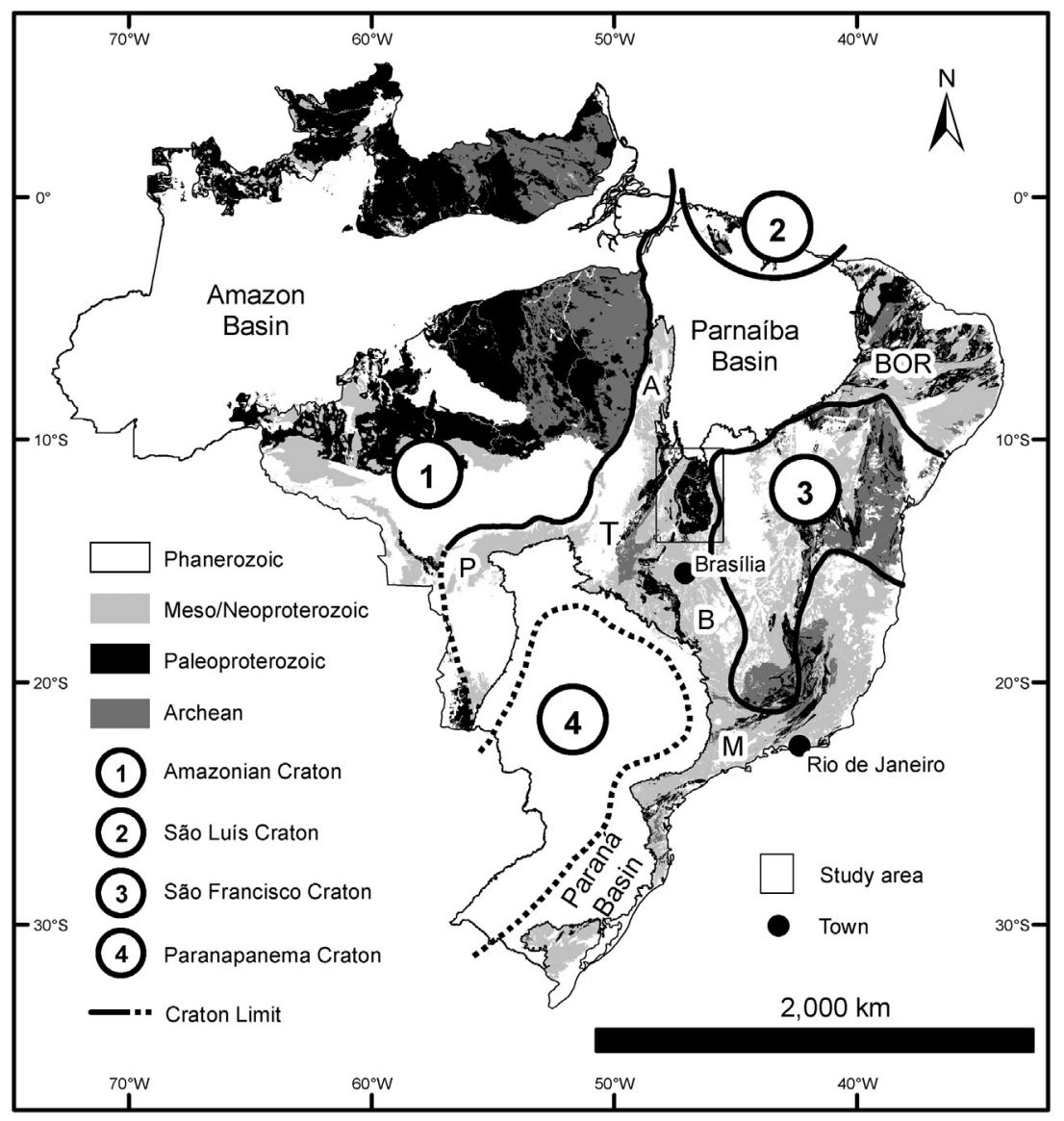

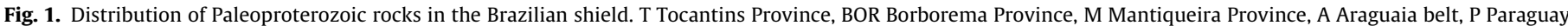
belt, B Brasília belt.

Based on Bizzi et al. (2003).

(Cordani et al., 2003a,b; Zhao et al., 2006; Fuck et al., 2008). However, little is known about the constitution and geometry of the large landmasses that existed between c. 2.0 and $1.8 \mathrm{Ga}$ until the formation of Gondwana (Rogers and Santosh, 2002). Another important point addressed is the presence of juvenile rocks formed at approximately $2.3 \mathrm{Ga}$, which are quite rare in the geological record (Condie, 1994, 2002).

In central Brazil, the basement underlying the external domain of the Neoproterozoic Brasília Belt is c. $30,000-\mathrm{km}^{2}$-crust fragment, informally called Cavalcante-Natividade block. It is considered as exposure of the western part of the São Francisco plate (Cordani and Sato, 1999; Cordani et al., 2000; Fuck et al., 2008; Brito Neves, 2011), which was reworked during the Neoproterozoic Brasiliano Orogeny. Several questions remain unresolved concerning the tectonic evolution of this Paleoproterozoic terrain and will be addressed in this study. Some of these questions are: (i) Does it represent collisional or accretionary orogens? (ii) Are arc systems preserved in this area? (iii) What was the duration of the Paleoproterozoic magmatic events? (iv) What is the relevance of this large terrain for the reconstruction of Paleoproterozoic supercontinents?

In general, only Paleoproterozoic terrains within larger cratons such as the São Francisco and Amazonian cratons are taken into consideration in Paleoproterozoic-Mesoproterozoic supercontinent reconstructions, while smaller crustal segments such as the one investigated here have been neglected (e.g. Unrug, 1996; Condie et al., 2000; Zhao et al., 2006; Reddy and Evans, 2009; Evans and Mitchell, 2011). One of the basic questions to be addressed refers to the relationship between the CavalcanteNatividade crustal block and the sialic basement exposed in the
São Francisco Craton, to the east. The Cavalcante-Natividade block may represent just the continuity of the craton sialic basement rock units or, alternatively, it may constitute an exotic fragment accreted to the western border of the São Francisco Craton during Paleoproterozoic orogenies, or even during late stages of evolution of the Neoproterozoic Brasília Belt.

The main objectives of this work are to investigate: (i) the history of crustal growth of the granite-gneiss complex in order to better understand the pre-Brasiliano crustal evolution of the northeastern sector of the Tocantins Province, (ii) the nature of the western limit of the Paleoproterozoic terrains and their relationships with the juvenile Neoproterozoic rock units of the Goiás Magmatic Arc, to the west.

New conventional $\mathrm{U}-\mathrm{Pb}$ data of both single and multigrain zircon fractions are presented, along with Sm-Nd whole-rock data from orthogneisses exposed in southeast Tocantins and northeast Goiás, central Brazil. Aditionally, data of zircon grains from three samples analyzed by ICPMS and from two samples analyzed by SHRIMP are also presented.

\section{Geologic setting}

The Tocantins Province (Almeida et al., 1981; Marini et al., $1984 a, b)$ in central Brazil is a large Neoproterozoic (BrasilianoPan African) orogen resulting from the convergence and collision of three major continental blocks: the Amazonian continent in the west, the São Francisco-Congo continent in the east, and the Paranapanema block in the south, presently covered by Phanerozoic rocks of the Paraná Basin (Fig. 1). Minor continental fragments, 
which might have also been involved in the development of the Tocantins Province, are concealed beneath the Phanerozoic sedimentary rocks of the Parnaíba basin to the north (Cordani et al., 1984; Brito Neves et al., 1984; Fuck et al., 2008).

Three Neoproterozoic fold belts are identified as the main constituents of the Tocantins Province: the Araguaia and Paraguay belts extend along the eastern and southeastern margins of the Amazonian Craton, respectively, and the Brasília Belt, exposed along the western edge of the São Francisco Craton (Figs. 1 and 2). The Brasília Belt extends for more than $1000 \mathrm{~km}$ in the $\mathrm{N}-\mathrm{S}$ direction. It constitutes one of the best preserved and more complete Brasiliano orogens in South America, with thick continental margin sedimentary sequences, ophiolite fragments, a large juvenile magmatic arc, and an important gravimetric anomaly indicative of a suture between the continental blocks involved (Pereira and Fuck, 2005 and references therein). Its main features indicate that the final structural differentiation of the Brasília Belt resulted from the closure of a wide ocean basin during the Neoproterozoic Brasiliano Orogeny (Pimentel and Fuck, 1992; Pimentel et al., 1997, 2000, 2004; Soares et al., 2006). Therefore, the Brasília Belt provides important information for understanding the processes that led to the assembly of West Gondwana at the end of the Proterozoic (Trompette, 1994; Pimentel et al., 2000, 2004; Valeriano et al., 2008).

The Brasília Belt can be divided into three major branches: the northern branch, striking in the NNE-SSW direction, is separated from the NNW-SSE striking central-southern branch by the WNW-ESE Pireneus syntaxis (Araújo Filho, 2000; Pimentel et al., 2000, 2004; Figs. 1 and 2); the southernmost branch wraps around the southern tip of the São Francisco Craton, striking mainly E-W (Trouw et al., 2000; Campos Neto, 2000; Valeriano et al., 2004, 2008; Campos Neto et al., 2011). Despite important differences recorded along the belt, several tectonic domains may be recognized (Fuck et al., 1994; Pimentel et al., 2000, 2004; Dardenne, 2000; Valeriano et al., 2004, 2008). The eastern external zone is a craton-verging fold-and-thrust belt, comprising thick passive margin sedimentary deposits, deformed under very lowgrade greenschist facies metamorphism. To the north, the folded metasedimentary sequences thin out, and large areas of their sialic basement, encompassed in the Cavalcante-Natividade crustal block, are exposed, including granite-gneiss terrains with minor volcano-sedimentary sequences (Figs. 2 and 3). The internal western part of the belt comprises: (i) the metamorphic core of the belt, made of the Anápolis-Itauçu granulites, presenting local ultrahigh temperature mineral assemblages, separated by faults from the mainly turbiditic lower grade metasedimentary rocks of the Araxá Group which include small ophiolite remnants, comprising MORB-type ocean-floor metabasalt and serpentinezed peridotite, (ii) the Goiás Massif made of Archean granite-greenstone terrains, Paleoproterozoic orthogneiss largely covered by folded metasedimentary sequences, and mafic-ultramafic layered intrusions and associated volcano-sedimentary sequences of Mesoproterozoic and Neoproterozoic ages, (iii) the Goiás Magmatic Arc, a Neoproterozoic juvenile arc terrain, comprising c. 930-800 Ma old calc-alkaline orthogneiss and remnants of volcano-sedimentary sequences, and younger orthogneiss and supracrustals of continental arc affinity (670-600 Ma), as well as a number of late- to post-orogenic granite intrusions.

\subsection{The Cavalcante-Natividade crustal block}

The Cavalcante-Natividade crustal block (Fig. 2) represents the sialic basement of Late Paleoproterozoic and Neoproterozoic supracrustal sequences in the northeastern part of the Brasília Belt. In the south it is covered by the Late Paleoproterozoic Araí Group (c. $1.77 \mathrm{Ga}$ ), which consists of conglomerates, sandstones and bimodal volcanic rocks at the base, forming a typical continental rift sequence, which is followed by a thick pile of shallow marine sandstone, siltstone, pelite and minor carbonate. Bimodal volcanism is accompanied by coeval anorogenic granite intrusions, followed by a younger, c. $1.58 \mathrm{Ma}$, phase of tin-mineralized anorogenic granite intrusions (Pimentel et al., 1991, 1999; Pimentel and Botelho, 2001; Alvarenga et al., 2007). Westwards and southwards Neoproterozoic passive margin sedimentary and metasedimentary rocks forming the fold-and-thrust belt cover the Araí Group and basement rocks. Eastwards, scarce, discontinuous diamictite layers of the Jequitaí Formation (not shown due to scale) and, more commonly, carbonate and fine-grained siliciclastic rocks of the Bambuí Group, both Late Neoproterozoic in age, overlie the basement rocks. Traditionally the western limit of the mostly undeformed Bambuí rocks is taken as the western limit of the São Francisco Craton (Fuck et al., 1994; Pimentel et al., 2000, 2004; Dardenne, 2000; Alkmim, 2004; Valeriano et al., 2008). In the north the gneiss terrain is covered by conglomerate, sandstone, siltstone and carbonate rocks of the Natividade Group, considered to be equivalent to the Araí Group. Further north and northeast Phanerozoic sedimentary deposits of the Parnaíba and Sanfranciscana basins cover the Proterozoic rocks, including the Cavalcante-Natividade block.

To the west, the Cavalcante-Natividade block is in contact with a narrow strip of gneiss terrain belonging to the Goiás massif through a strike-slip shear zone and the Rio Maranhão thrust further south (Fig. 2). Southwards, the Serra da Mesa Group amphibolite facies supracrustal rocks cover the Goiás massif basement and wrap around large granite and alkaline intrusions. The depositional age of these supracrustals is not well constrained, although it has been suggested that they might be equivalent to the stratigraphically upper units of the Araí Group (Fuck and Marini, 1979; Fuck et al., 1988; Marques, 2009). Between $13^{\circ}$ and $14^{\circ} \mathrm{S}$, the Goiás massif is enlarged and its eastern border is marked by the Cana Brava layered mafic-ultramafic intrusion and associated Palmeirópolis volcanosedimentary sequence (Fig. 3). Westwards, the massif is in contact with juvenile arc rocks of the Neoproterozoic Goiás Magmatic Arc through a dextral strike-slip shear zone, which appears to merge southwards with the Rio dos Bois thrust fault (Fig. 2). Both strikeslip faults are ascribed to the Transbrasiliano lineament (Fig. 2), a continental scale discontinuity extending from Ceará, in northeast Brazil, to Argentina (Schobbenhaus et al., 1975; Fuck et al., 2011). The northwestern limit of the Goiás arc is marked by another dextral strike-slip fault of the Transbrasiliano lineament, separating it from Paleoproterozoic gneiss and granulite terrains of the basement of the Araguaia belt (Fig. 2). These terrains include the 2.14 Ga Porto Nacional granulite complex and the Rio dos Mangues complex comprising tonalite and granodiorite orthogneiss dated at 2.12-2.05 Ga, as well as restricted supracrustal sequences (Gorayeb et al., 2013). A number of granites intruded the basement, some at $2.08 \mathrm{Ga}$, like the Ipueiras suite, others with ages around $0.55 \mathrm{Ga}$ (Lajeado suite, Gorayeb et al., 2013).

The rock units forming the Cavalcante-Natividade terrain are poorly known. Most of the area has been investigated only by smallscale surveys (Barbosa et al., 1969; Costa et al., 1976; Araújo and Alves, 1979; Correia Filho and Sá, 1980; Fernandes et al., 1982). A few areas were studied in more detail, such as Almas-Dianópolis (Costa, 1985; Cruz and Kuyumjian, 1998, 1999; Cruz, 2001), AlmasConceição do Tocantins (Padilha, 1984), Cavalcante-Teresina de Goiás-Campos Belos-Nova Roma (Botelho, 1992; Botelho et al., 1995, 1998, 1999; Alvarenga et al., 1999, 2007), Arraias (Campos et al., 2001), Paranã (Campos et al., 2010), and Natividade (Gorayeb et al., 1988; Oliveira et al., 2012). Recently, CPRM (Geological Survey of Brazil) undertook the mapping of the region in 1:250,000 scale. The Gurupi sheet has been completed (Frasca et al., 2010), whereas the Arraias and Dianópolis sheets are underway. 


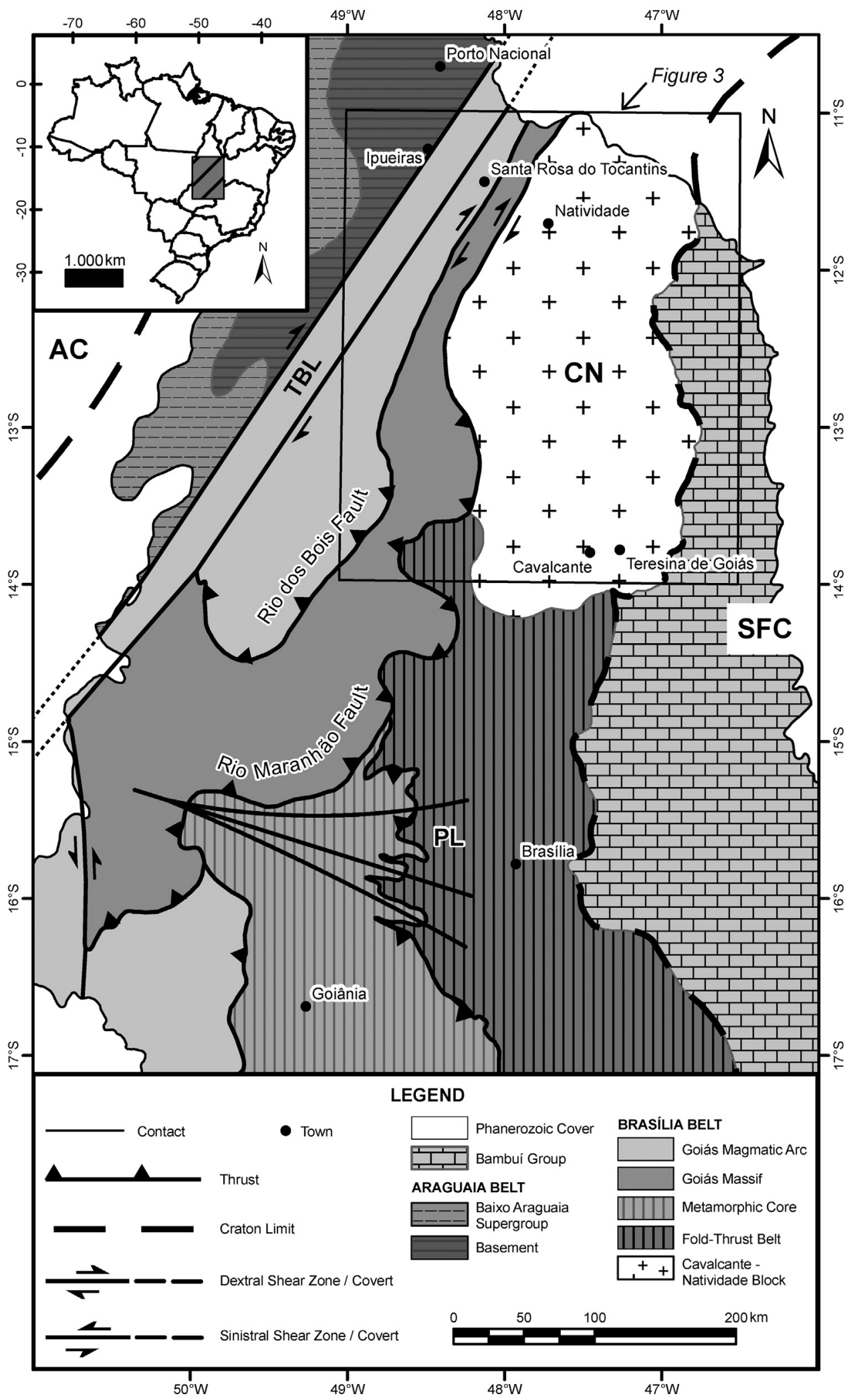

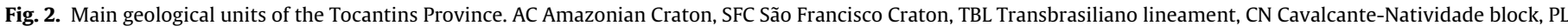
Pirineus lineament.

Based on Bizzi et al. (2003). 


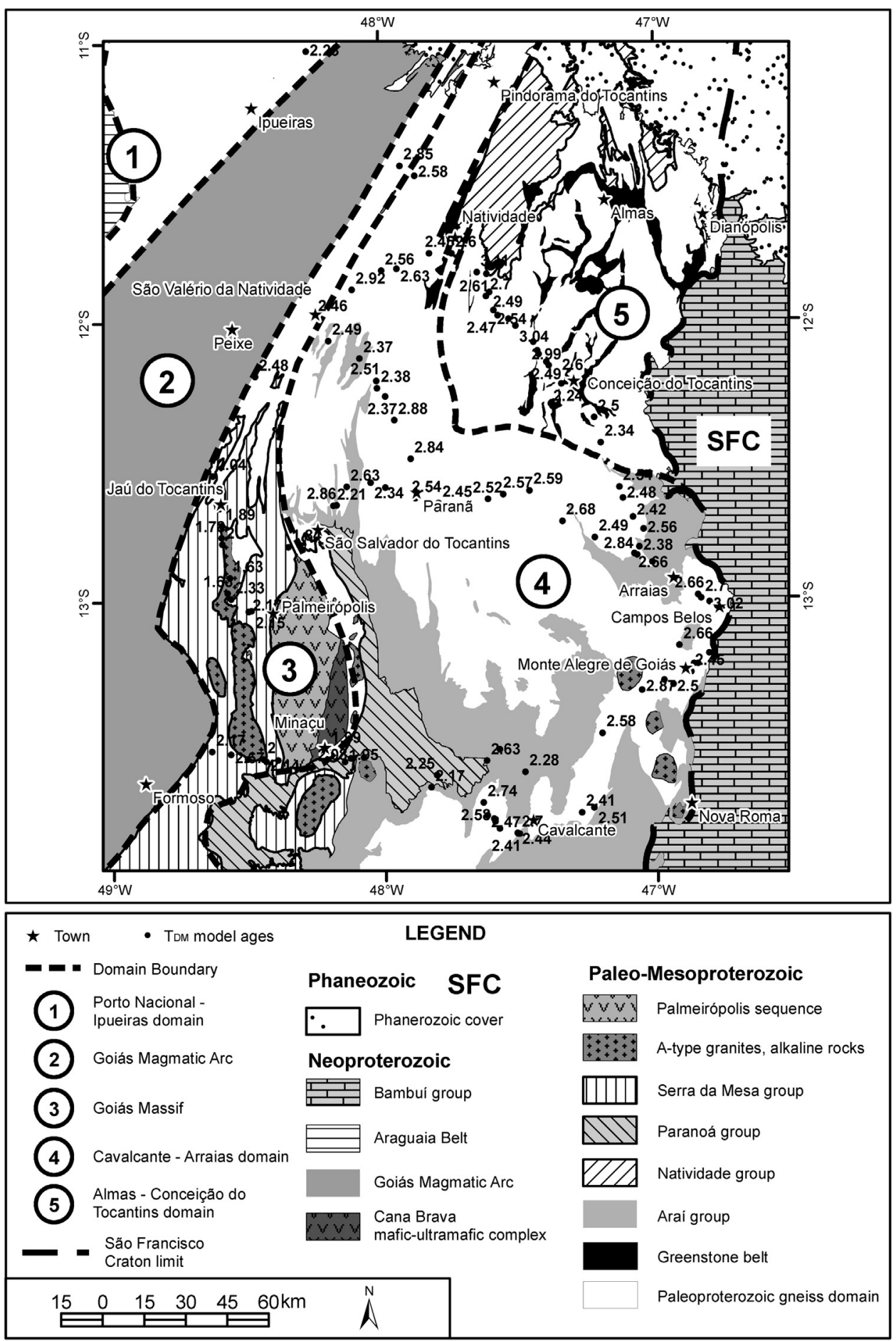

Fig. 3. Nd isotopic map of the Paleoproterozoic Cavalcante-Natividade block and adjacent areas.

As far as rock types are concerned, two main domains may be recognized within the Cavalcante-Natividade block. The northeastern part of the block, the Almas-Conceição do Tocantins domain (Cruz, 2001), is characterized by granite-gneiss associated with supracrustal sequences (Fig. 3). Amphibole schist, representing basalt flows, including pillowed basalt, sericite and chlorite phyllite, banded iron formation, quartzite, and subordinate felsic tuff form narrow belts striking N-S and NNE-SSW, locally wrapping around granite-gneiss domes, particularly in the northern Almas-Dianópolis area (Costa et al., 1976; Costa, 1985; Cruz and Kuyumjian, 1998; Borges et al., 1998; Kuyumjian et al., 2012).
Originally this association was interpreted as an Archean granitegreenstone terrain (Costa et al., 1976; Padilha, 1984). Radiometric determinations by the $\mathrm{Rb}-\mathrm{Sr}$ method resulted in Archean ages, ranging from 2.5 to $2.9 \mathrm{Ga}$ in rocks collected near Dianópolis (Bernasconi, 1983). Recently, a felsic volcanic rock sampled in one of these supracrustal belts close to Natividade was dated at $2206 \pm 13 \mathrm{Ma}$ (Dardenne et al., 2009).

Two calc-alkaline granitoid associations were recognized in the Almas-Cavalcante domain (Thomsen and Kuyumjian, 1994; Cruz and Kuyumjian, 1996, 1998; Cruz, 2001; Cruz et al., 2003; Kuyumjian et al., 2012). The oldest association intrudes the 
supracrustal rocks and comprises low-Al hornblende-bearing tonalite, trondhjemite, granodiorite and quartz diorite. Foliation is weak in the east, close to the São Francisco craton border, becoming more prominent westwards where banded structures are common. The younger granitoid association comprises high-Al biotite-bearing tonalite and granodiorite, forming several ovalshaped plutons, which intruded both the supracrustal rocks and the older granitoid association. Foliation in the intrusions is weak, being more prominent along the margins of the plutons and along shear zones. Major and trace elements suggest that the parental magma of the hornblende-bearing association is derived possibly from the mantle, whilst the biotite-bearing tonalite and granodiorite intrusions derived from melting of subducted metabasalt (Cruz and Kuyumjian, 1996, 1998; Cruz et al., 2003). Granitoid rocks with similar mineralogy and geochemistry were recognized in the Conceição do Tocantins area (Thomsen and Kuyumjian, 1994; Kuyumjian and Araújo Filho, 2005). SHRIMP U-Pb zircon dating yielded ages of $2.2 \mathrm{Ga}$ for both low-Al and high-Al suites, although titanite from the Ribeirão das Areias complex, ascribed to the highAl biotite-bearing suite, was dated at c. $2.45 \mathrm{Ga}$ (Cruz, 2001; Cruz et al., 2003). Both supracrustal and granitoid rocks were deformed by oblique thrust zones and ductile, mostly right-lateral strike-slip zones (Borges et al., 1999).

The remaining parts of the Cavalcante-Natividade crustal block, extending from Cavalcante in the south to Arraias, Paranã in the west, and beyond Natividade up to Pindorama do Tocantins in the north, displays basement dominated by peraluminous granitoid rocks. In the Cavalcante-Nova Roma-Campos Belos area, from oldest to youngest, the peraluminous granite association, known as the Aurumina suite (Botelho et al., 1999, 2006; Alvarenga et al., 2007), encompasses muscovite monzogranite, muscovite-biotite monzogranite, tonalite, biotite syenogranite and tourmaline-bearing leucogranites and pegmatites. Although the peraluminous rock association has been mapped in detail in the Cavalcante-Monte Alegre de Goiás area (Alvarenga et al., 2007), as well as in Arraias and Paranã and surroundings (Campos et al., 2001, 2010; Marques, 2009), its limits and relationship with the Almas-Conceição do Tocantins domain remain poorly known. However, recent mapping in the Natividade area points to peraluminous granites intruding metaluminous orthogneiss of the Almas-Conceição do Tocantins domain (Oliveira et al., 2012). Granites of the Aurumina suite are intrusive into graphite-bearing schist and paragneiss of the Ticunzal Formation which is exposed as narrow strips a few hundred meters up to 1-2 km wide (Botelho et al., 2006; Alvarenga et al., 2007). Syn- to late-tectonic intrusion relationships are indicated by lit-par-lit type structures and other migmatite features, mainly related with metasedimentary inclusions and along the contact with the Ticunzal Formation. Fine-grained graphite lamellae and centimeter-sized graphite-rich nodules interpreted as probable restites are common in the Aurumina granites (Botelho et al., 2006).

All petrographic facies of the Aurumina suite so far studied display mineral and chemical features, such as igneous muscovite and graphite restite, indicating the peraluminous nature of the granitoids, compatible with the interpretation that they represent synto post-collisional intrusions, derived from crustal melting (Botelho et al., 2006; Alvarenga et al., 2007).

$\mathrm{U}-\mathrm{Pb}$ zircon data indicate ages between 2.12 and $2.17 \mathrm{Ga}$ for the Aurumina suite (Botelho et al., 2006). The younger ages are consistent with the c. $2.1 \mathrm{Ga} \mathrm{U}-\mathrm{Pb}$ and $\mathrm{Pb}-\mathrm{Pb}$ ages of cassiterite from the Monte Alegre de Goiás tin deposits and with the c. $2.1 \mathrm{Ga}$ $\mathrm{K}-\mathrm{Ar}$ ages of muscovite from Sn-pegmatites (Sparrenberger and Tassinari, 1999), suggesting that the crystallization of magmas and tin-bearing hydrothermal systems are roughly coeval. Granites and tonalites display $\varepsilon_{\mathrm{Nd}}(t)$ values between -1 and -3 and $T_{\mathrm{DM}}$ values between 2.4 and $2.6 \mathrm{Ga}$, indicating that the peraluminous magmas are mainly derived from or are heavily contaminated with
Paleoproterozoic metasedimentary rocks. In the geological context of the Aurumina suite, the Ticunzal Formation is the oldest rock unit $(>2.2 \mathrm{Ga}$ ) recognized so far, probably derived from the erosion of Paleoproterozoic and possibly Archean sources, as indicated by $T_{\mathrm{DM}}$ model ages ranging from 2.5 to $2.8 \mathrm{Ga}$ (Botelho et al., 2006). According to these authors, the peraluminous nature of the Aurumina suite, its geological and geotectonic relationships with the Ticunzal Formation, the occurrence of migmatites and residual graphite or graphite-bearing xenoliths, combined with the $\mathrm{U}-\mathrm{Pb}$ and Sm-Nd data, suggest that the Ticunzal metasedimentary rocks are the most likely source of the Aurumina granite magmas.

The peraluminous Aurumina suite is frequently foliated, with foliation and banding striking mainly NNE-SSW, particularly close to shear zones. Exceptions are younger granite and tonalite, which usually display undisturbed igneous textures.

$\mathrm{U}-\mathrm{Pb}$ zircon ages are not available for the northern part of this domain. However, previous regional-scale geochronological studies based mainly on $\mathrm{Rb}-\mathrm{Sr}$ and $\mathrm{K}-\mathrm{Ar}$ data suggest that the whole block is of Paleoproterozoic age (Hasui et al., 1980). K-Ar ages of c. $1500,900,800$, and 500 Ma were taken as the result of partial isotopic resetting due to the Late Neoproterozoic Brasiliano orogeny (Hasui et al., 1980).

The main objective of the present study is to assess time intervals of magmatic events, using conventional TIMS, LA-ICPMS and SHRIMP U-Pb zircon dating of representative samples from the different domains recognized. In addition, Sm-Nd isotopic data are used to distinguish different events of continental crust formation in the basement of the northeast portion of the Brasília Belt. Analytical results are presented in Tables 1a, 1b and 2-4.

\subsubsection{Analytical procedures}

2.1.1.1. $U-P b$. Zircon concentrates were extracted from c. $10 \mathrm{~kg}$ rock samples, using magnetic (Frantz isodynamic separator) technique at the Geochronology Laboratory of Universidade de Brasília. Mineral fractions were handpicked under a binocular microscope to obtain fractions of similar size, shape and color.

For the conventional $\mathrm{U}-\mathrm{Pb}$ analyses, multi- and singlegrain fractions were dissolved in concentrated $\mathrm{HF}$ and $\mathrm{HNO}_{3}$ ( $\mathrm{HF}: \mathrm{HNO}_{3}=4: 1$ ), using microcapsules in Parr-type bombs. A mixed ${ }^{205} \mathrm{~Pb}-{ }^{235} \mathrm{U}$ spike was used. Chemical extraction followed standard anion exchange technique, using Teflon micro-columns, following procedures modified from Krogh (1973). Pb and U were loaded together on single Re filaments with $\mathrm{H}_{3} \mathrm{PO}_{4}$ and $\mathrm{Si}$ gel, and isotopic analyses were carried out on a Finnigan MAT-262 multi-collector mass spectrometer equipped with secondary electron multiplierion counting, at the Geochronology Laboratory of Universidade de Brasília. Procedure blanks for $\mathrm{Pb}$, at the time of analyses, were better than 20 pg. PBDAT (Ludwig, 1993) and ISOPLOT-Ex (Ludwig, 2001a) were used for data reduction and age calculation. Errors for isotopic ratios are $2 \sigma$.

For ion microprobe and LA-ICPMS analyses, handpicked zircon grains were mounted in epoxy blocks and polished to obtain an even surface. Cathodoluminescence imagery in a scanning electron microscope was used to investigate the internal structures of the zircon crystals prior to analysis.

Before LA-ICPMS analyses, mounts were cleaned by carefully rinsing with dilute (c. $2 \%$ ) HNO3. Once fully dry, the samples were mounted in a specially adapted laser cell for thick sections, and loaded into a UP213 Nd:YAG laser $(\lambda=213 \mathrm{~nm})$, linked to a Neptune ICPMS at the Geochronology Laboratory of Universidade de Brasília. Helium was used as carrier gas and mixed with argon before entering the ICP. Each analysis was studied and only coherent intervals, with no signals of mixed age data or intercept of secondary phase or fracture, were chosen for final age calculation. Normalization to GJ standard zircon (608.5 $\pm 1.5 \mathrm{Ma}$; Jackson et al., 2004) and age calculations were performed using an in-house developed Excel ${ }^{\circledR}$ 
worksheet, based on ISOPLOT v.3 formulae (Ludwig, 2003). ${ }^{204} \mathrm{Hg}$ and ${ }^{202} \mathrm{Hg}$ were measured to assess isobaric interference on ${ }^{204} \mathrm{~Pb}$. Corrections for common $\mathrm{Pb}$ were carried out in analyses presenting ${ }^{206} \mathrm{~Pb} /{ }^{204} \mathrm{~Pb}$ lower then 1000 , using the Stacey and Kramers (1975) model at the age of crystallization. Plotting of $\mathrm{U}-\mathrm{Pb}$ data was performed by ISOPLOT v.3 (Ludwig, 2003). Errors for isotopic ratios are presented at the $2 \sigma$ level.

Ion microprobe analyses were carried out using SHRIMP I at the Research School of Earth Sciences, Australian National University, Canberra, Australia. Data were collected and reduced as described by Williams and Claesson (1987) and Compston et al. (1992). Uncertainties are given at $1 \sigma$ level, and final age is quoted at $95 \%$ confidence level. Reduction of raw data was carried out using Squid 1.02 (Ludwig, 2001b). U/Pb ratios were referenced to the RSES standard zircon AS3 $\left(1099 \mathrm{Ma},{ }^{*} 206 \mathrm{~Pb} /{ }^{238} \mathrm{U}=0.1859\right.$, Paces and Miller, 1989). U and Th concentrations were determined relative to those measured in the RSES standard SL13.

2.1.1.2. Sm-Nd isotopic analyses. Sm-Nd isotopic analyses followed the method described by Gioia and Pimentel (2000) and were carried out at the Geochronology Laboratory of the Universidade de Brasília. Whole-rock powders (c. $50 \mathrm{mg}$ ) were mixed with ${ }^{149} \mathrm{Sm}-{ }^{150} \mathrm{Nd}$ spike solution and dissolved in Savillex capsules. Sm and $\mathrm{Nd}$ extraction of whole-rock samples followed conventional cation exchange techniques, using Teflon columns containing LNSpec resin (HDEHP-diethylhexil phosphoric acid supported on PTFE powder). Sm and Nd samples were loaded on Re evaporation filaments of double filament assemblies and the isotopic measurements were carried out on a multi-collector Finnigan MAT 262 mass spectrometer in static mode. Uncertainties for Sm/Nd and ${ }^{143} \mathrm{Nd} /{ }^{144} \mathrm{Nd}$ ratios are better than $\pm 0.5 \%(2 \sigma)$ and $\pm 0.005 \%$ $(2 \sigma)$, respectively, based on repeated analyses of international rock standards BHVO-1 and BCR-1. ${ }^{143} \mathrm{Nd} /{ }^{144} \mathrm{Nd}$ ratios were normalized to ${ }^{146} \mathrm{Nd} /{ }^{144} \mathrm{Nd}$ of 0.7219 and the decay constant used was $6.54 \times 10^{-12} \mathrm{a}^{-1}$. $T_{\text {DM }}$ values were calculated using DePaolo's (1981) model.

In our research we analyzed approximately 50 samples of the most representative plutonic rocks, occurring in the area for the Sm-Nd methodology and 11 selected samples for $\mathrm{U}-\mathrm{Pb}$ geochronology.

\section{Results}

The systematic study of Nd isotopes allowed identifying several crustal domains with distinct isotopic signatures separated by large shear zones (Tables $1 \mathrm{a}$ and $1 \mathrm{~b}$, Fig. 2). The results will be, therefore, discussed according to this tectonic subdivision of this portion of Tocantins Province: Cavalcante-Arraias, Almas-Conceição do Tocantins, Goiás Magmatic Arc, and Porto Nacional-Ipueiras domains (Fig. 3).

\subsection{Almas-Conceição do Tocantins domain}

Samples investigated in the present study are from the southwestern part of this domain, between Conceição do Tocantins and Natividade (Fig. 3). Two different magmatic events are recognized.

The older event took place during the Early Paleoproterozoic and is represented by samples NAT 2 and CONTO-6. Biotite tonalite gneiss (NAT 2) has euhedral, prismatic and clear zircon grains. Analytical points align along a discordia defining the upper intercept age of $2343 \pm 11 \mathrm{Ma}$ (Fig. 4C), interpreted as the best estimate for the igneous crystallization age. Sample CONTO-6 represents deformed granite gneiss. Analytical points taken from clear, long, prismatic, single grain zircon crystals are aligned along a discordia pointing to the crystallization age of $2379 \pm 6 \mathrm{Ma}$ (Fig. 4D). The rocks from this domain are characterized by $T_{\mathrm{DM}}$ model ages ranging between 2.5 and $2.6 \mathrm{Ga}$. $\varepsilon_{\mathrm{Nd}}(t)$ values range from +2 to close to zero, suggesting considerable input from juvenile sources for continental crust formation. Therefore, the data indicate an Early Paleoproterozoic juvenile magmatic arc event in central Brazil. Although the samples were collected in a relatively restricted area, available geological field data do not allow inferring if they represent a coherent Early Paleoproterozoic sub-domain within the Almas-Conceição do Tocantins domain.

The younger event is apparently the dominant magmatism and comprises hornblende-biotite tonalite intrusions. Tonalite sample NAT 8 shows the age of $2180 \pm 12 \mathrm{Ma}$ (Fig. 4E). Zircon crystals from a coarse-grained foliated biotite granite (sample CONTO 11), located c. $50 \mathrm{~km}$ northwest of Conceição do Tocantins, yielded an upper intercept age of $2144 \pm 21 \mathrm{Ma}$ (Fig. $4 \mathrm{~F}$ ). Negative $\varepsilon_{\mathrm{Nd}}(t)$ values and $T_{\mathrm{DM}} \mathrm{Nd}$ model ages of approximately $2.5 \mathrm{Ga}$, indicate that the original magmas assimilated varied degrees of older continental crust.

Remmants of supracrustal belts are a typical feature of the Almas-Conceição do Tocantins area. Samples of metasedimentary rocks from one of these belts exposed close to Conceição do Tocantins have Sm-Nd $T_{\mathrm{DM}}$ model ages ranging between 2.7 and $3.0 \mathrm{Ga}$ (Table 2 ). Their $\varepsilon_{\mathrm{Nd}}(t)$ values are negative, approximately -8 , suggesting derivation from Archean sialic sources. As mentioned before, a felsic volcanic rock sample from close to Natividade yielded a zircon $\mathrm{U}-\mathrm{Pb}$ age of $2206 \pm 13 \mathrm{Ma}$ (Dardenne et al., 2009).

Northwards low-grade rocks of the Natividade Group cover orthogneiss and associated supracrustal belts. The age of the cover rocks is not well constrained, but they have been taken as equivalents of the Late Paleoproterozoic Araí Group (Correia Filho and Sá, 1980), although some workers have suggested possible correlation with the Neoproterozoic Bambuí Group (Hasui et al., 1990).

\subsection{Cavalcante-Arraias domain}

The Cavalcante-Arraias domain surrounds the Almas-Conceição do Tocantins domain, extending northwards to the vicinities of Pindorama do Tocantins. Westwards it is limited against the Goiás Massif by a right-lateral strike-slip shear zone, which is part of the Transbrasiliano lineament. Southwards it extends from Arraias and Paranã to Monte Alegre de Goiás, Cavalcante and beyond, largely covered by the Araí Group, and disappearing below the Bambuí Group in the east (Fig. 3). In this domain, peraluminous granitoids belonging to the Aurumina suite are largely dominant (Botelho et al., 2006).

In the vicinity of Arraias, samples from two generations of peraluminous tonalitic rocks were selected for ID TIMS U-Pb dating. Zircon crystals from biotite tonalite gneiss sample ARRA- 5 are reddish elongate prisms. Single-grain analyses of these crystals define a upper intercept TIMS age of $2136 \pm 3 \mathrm{Ma}$ (Fig. 4A), which is interpreted as the best estimate for the crystallization age of the tonalite gneiss protolith.

Sample ARRA-9 is from a less deformed tonalite compared to ARRA-5, apparently belonging to a second event of tonalite intrusion. Analytical results define a discordia with the upper intercept of $2042 \pm 12 \mathrm{Ma}$ (Fig. 4B), interpreted as the intrusion age of this body. All zircon crystals of this sample are red and metamictic grains, showing evidence of strong $\mathrm{Pb}$ loss due to later tectonic events at around $600 \mathrm{Ma}$. Orthogneisses from the western part of the domain, in the Paranã area, are mainly of granodiorite composition, although tonalite and granite compositions are also present. Three single zircon grains of sample PARANÃ 12, a porphyritic biotite granite gneiss, are discordant and yield the upper intercept age of $2170 \pm 19 \mathrm{Ma}$ (Fig. $4 \mathrm{H}$ ), interpreted as the best estimate for crystallization of the igneous protolith. Samples Paranã 2 and 6 represent fine-grained banded biotite gneiss of granodiorite composition. LA-MC-ICPMS analyses of zircon grains from 
sample Paranã 2 yielded a concordia age of $2179 \pm 11 \mathrm{Ma}$ (Fig. 4I), taken as the crystallization age of the igneous protolith. LA-MCICPMS analytical points for zircon crystals from sample Paranã 6 are discordant, scattered along a discordia line, indicating the upper intercept age of $2183 \pm 24 \mathrm{Ma}$ (Fig. $4 \mathrm{~J}$ ).

The northern part of this domain, extending to Natividade and Pindorama do Tocantins, is made of muscovite-biotite and biotite gneiss, mainly of tonalite to granodiorite composition. SHRIMP analytical data for zircon from tonalite gneiss sample NAT- 8 are slightly
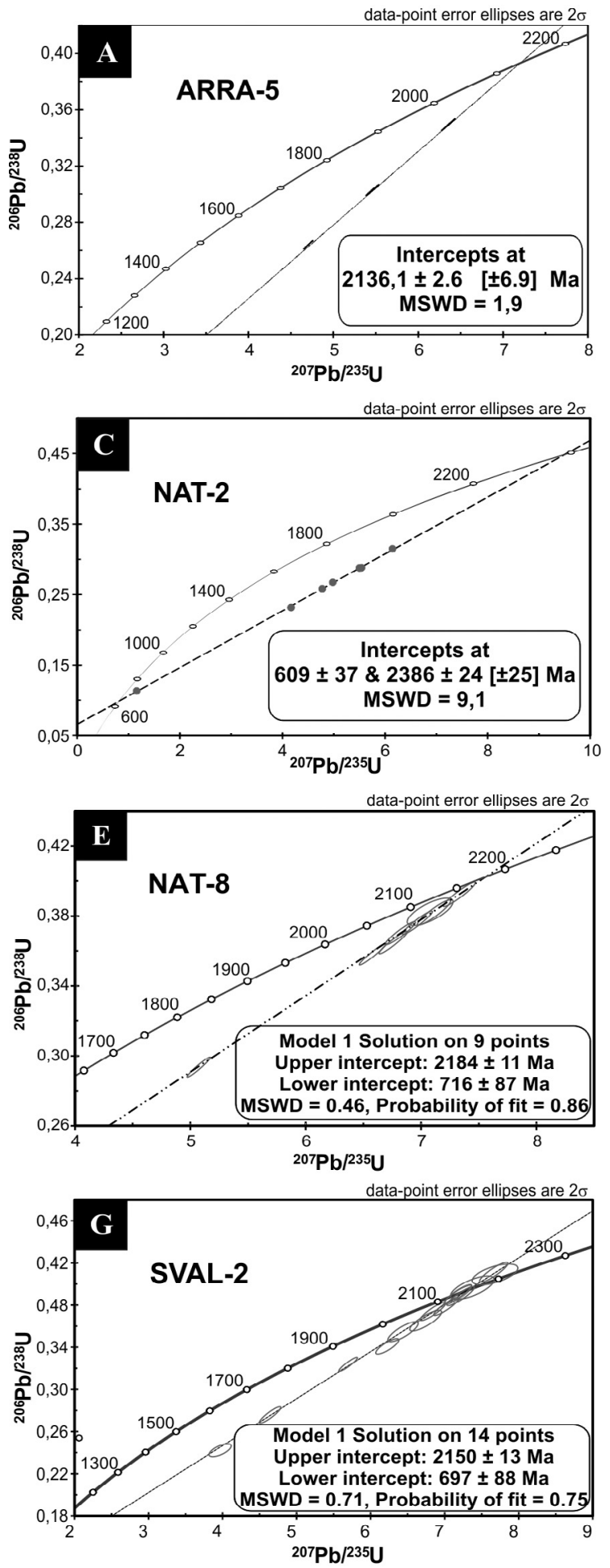

to moderately discordant and their alignment indicates an upper intercept at $2180 \pm 12 \mathrm{Ma}$ (Figs. $4 \mathrm{E}$ and $6 \mathrm{~b}$ ), interpreted as the age of crystallization of the igneous protolith.

Our results suggest that the time span of the peraluminous magmatism in the Arraias-Paranã-Natividade area is of about $50 \mathrm{Ma}$, constrained by zircon $\mathrm{U}-\mathrm{Pb}$ age data of samples Arra 5 $(2136 \pm 3 \mathrm{Ma})$ and Paranã $6(2183 \pm 24 \mathrm{Ma})$. The exception is sample ARRA 9, dated at $2042 \pm 12 \mathrm{Ma}$, upper intercept of a discordia line of scattered analytical points obtained on metamictic zircon
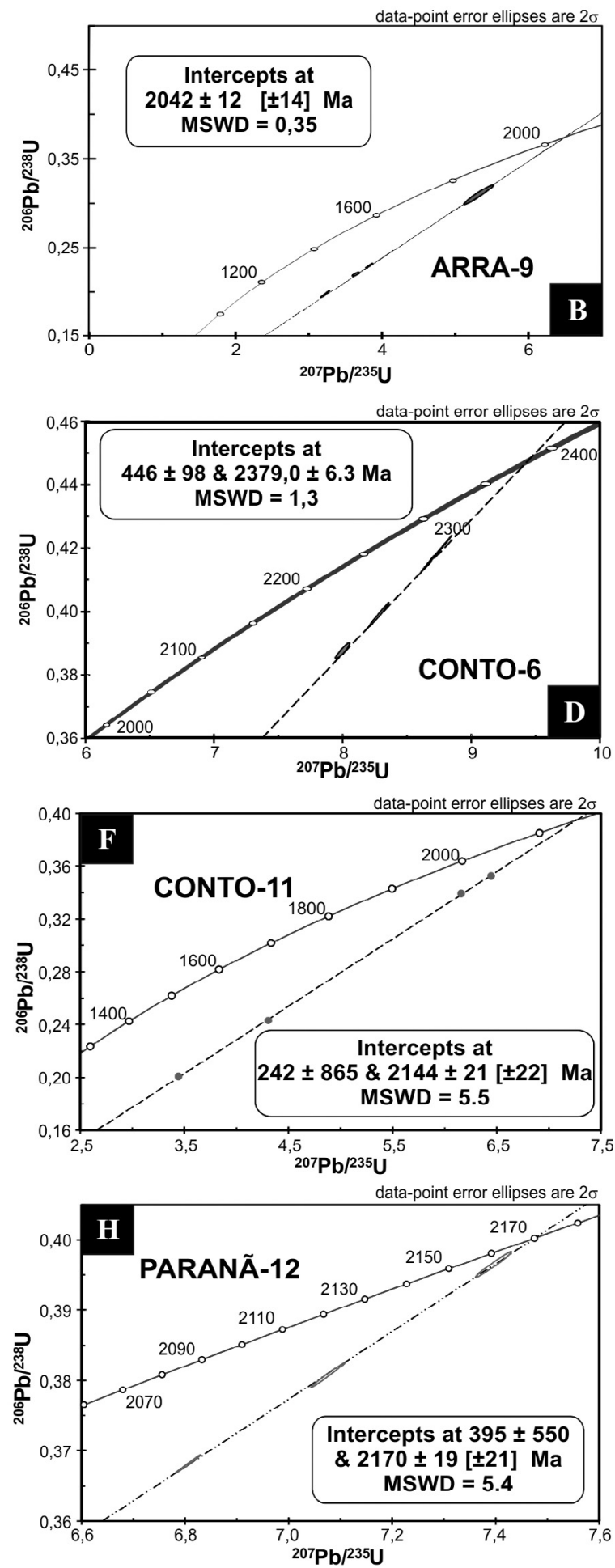

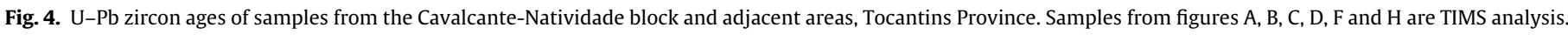
Samples from figures E, L, M and N are SHRIMP and I, J and K are ICPMS data. 

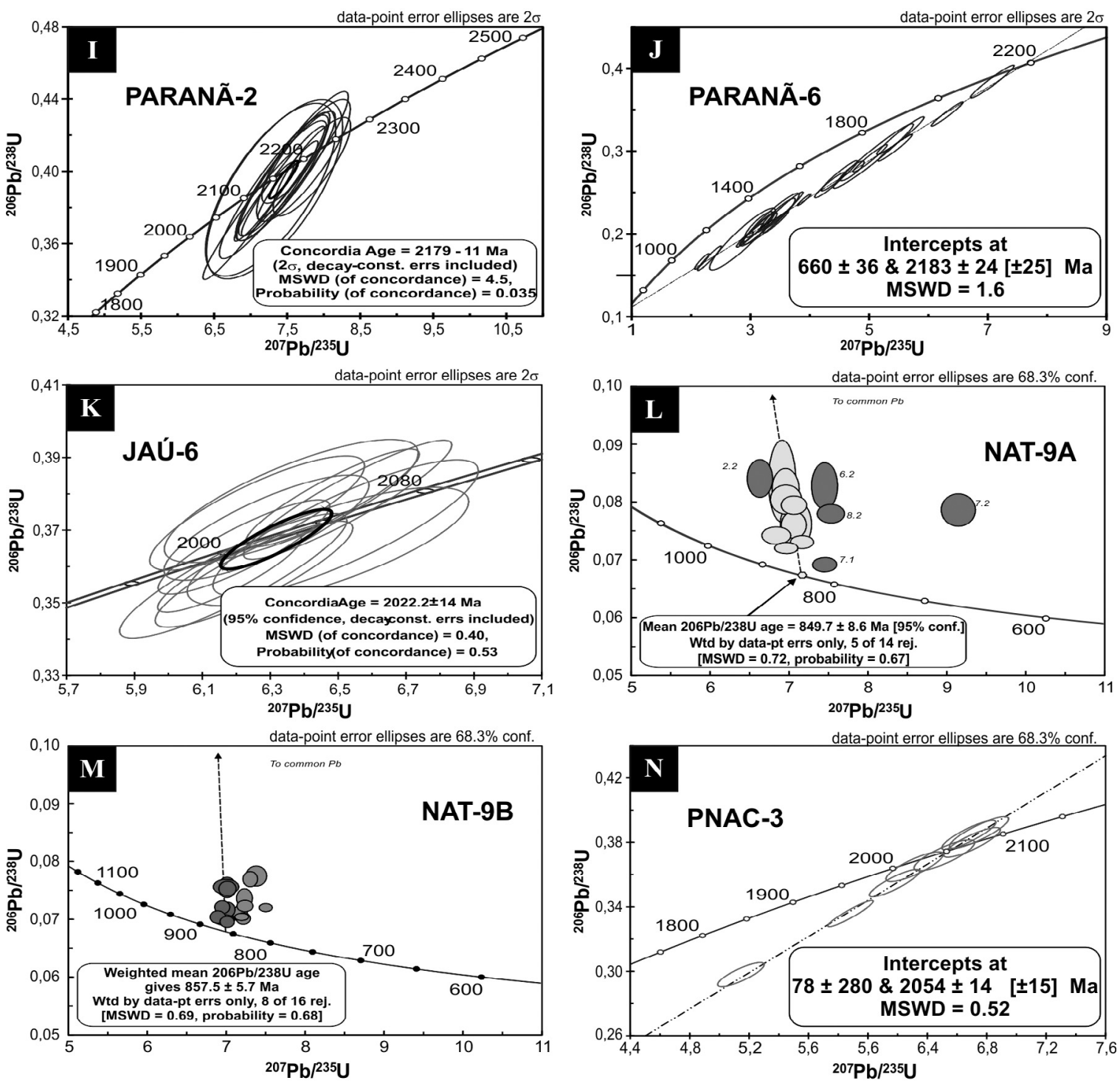

Fig. 4. (Continued).

grains, suggesting strong $\mathrm{Pb}$ loss at c. $600 \mathrm{Ma}$, possibly related to the Brasiliano orogeny. All samples analyzed from this domain show $T_{\mathrm{DM}}$ model ages between 2.4 and $2.8 \mathrm{Ga}$ and negative $\varepsilon_{\mathrm{Nd}}(t)$ values, around -3 , suggesting reworking of older continental crust or contamination with sedimentary country rocks.

\subsection{Goiás massif}

This domain encompasses basement orthogneiss located in a narrow strip between Jaú do Tocantins and São Valério da Natividade, and beyond (Fig. 3). The dominant basement rocks are granite- and granodiorite-gneiss, which are overlain by sedimentary rocks of the Proterozoic Serra da Mesa Group in the south. Southeastwards, the Goiás massif encompasses the Mesoproterozoic Palmeirópolis volcano-sedimentary sequence and associated Cana Brava layered mafic-ultramafic complex. To the west, the orthogneiss association is separated from the Neoproterozoic Goiás Magmatic Arc rocks along a dextral strike-slip shear zone that is part of the Transbrasiliano lineament.

Zircon analytical points for granodiorite sample SVAL-2 are concordant to slightly discordant. The discordia upper intercept defines the age of $2143 \pm 11 \mathrm{Ma}$, interpreted as the crystallization age of the igneous protolith. Sample Jaú 6 yielded a concordia age of $2022 \pm 14 \mathrm{Ma}$, taken as the crystallization age of the granite protolith (Figs. 4G and 6a).

Sm-Nd isotopic results for rock samples from the Goiás massif indicate $T_{\mathrm{DM}}$ model ages ranging between 2.04 and $2.85 \mathrm{Ga}$, and $\varepsilon_{\mathrm{Nd}}(T)$ values between +2 and -7 . Positive $\varepsilon_{\mathrm{Nd}}(T)$ values between +2 and $+0.2\left(T_{\mathrm{DM}}\right.$ model ages between 2.3 and $2.45 \mathrm{Ga}$ ) suggest that juvenile component took part in the continental crust formation event of the western domain of the NatividadeCavalcante crustal block. However, older $T_{\mathrm{DM}}$ model ages and negative $\varepsilon_{\mathrm{Nd}}(T)$ also indicate reworking of Archean continental crust (Fig. 5).

Preliminary results from the western part of the domain appear to indicate a somewhat different isotopic signature. $T_{\mathrm{DM}}$ model ages between 2.15 and $2.33 \mathrm{Ga}$ have been recorded. North of Jaú do Tocantins, sample Jaú- 6 of banded biotite gneiss with pegmatite veins has $T_{\mathrm{DM}}$ of $2.04 \mathrm{Ga}$. Zircon from this sample reveals a $\mathrm{U}-\mathrm{Pb}$ age of $2022 \pm 14 \mathrm{Ma}$. Work in progress is intended to clarify if the area belongs to a different, younger Paleoproterozoic crustal block (Fig. 4K). 


\subsection{Goiás Magmatic Arc}

The younger ages were found in samples of tonalite gneiss and one intrusive leucogranite from outcrops under the Rio Surubim bridge, some $50 \mathrm{~km}$ to the northwest of the town of Santa Rosa do Tocantins. SHRIMP U-Pb analyses of zircon grains of the tonalite gneiss sample (NAT-9A) and of the intrusive leucogranite (NAT9B) indicate that they crystallized c. $850 \mathrm{Ma}$ ago. Both rocks show prismatic, euhedral, and clear zircon grains (Fig. 4L and M).

They yield $T_{\mathrm{DM}}$ model ages of c. $1.3 \mathrm{Ga}$. The rocks show positive $\varepsilon_{\mathrm{Nd}}(t)$ values, characteristic of juvenile island arc source, and very similar to the results for tonalite gneiss from Mara Rosa, within the Goiás Magmatic Arc (Viana et al., 1995; Pimentel et al., 1997). Thus, these rocks attest to the presence of Neoproterozoic magmatic arc rocks in Tocantins, confirming the extension of the Goiás Magmatic Arc for more than $200 \mathrm{~km}$ northeastwards of their original discovery area.

\subsection{Porto Nacional-Ipueiras Domain}

Another crustal block is defined in the Porto Nacional region, where $T_{\mathrm{DM}}$ model ages for the basement rocks range mainly from 2.2 to $2.1 \mathrm{Ga}$. If the $2.15 \mathrm{Ga} \mathrm{U}-\mathrm{Pb}$ zircon evaporation ages of Gorayeb et al. (2000) are taken as representing an igneous event, a different segment of juvenile crust is identified in this terrain, where $\varepsilon_{\mathrm{Nd}}(t)$ values range from +1.9 to +3 . The Areia granite (PNAC-3), intrusive in the basement rocks, was dated using SHRIMP analysis and yielding an age of $2054 \pm 14$ Ma, suggesting different periods of Paleoproterozoic magmatism in the area (Figs. 4N and 6c).

Also, in this block several gneiss samples present $T_{\mathrm{DM}}$ model ages varying from 1.89 to $1.49 \mathrm{Ga}$ and extremely negative $\mathrm{Nd} t$ values, around -7 , attesting that young, Neoproterozoic sources play an important role in the reworked continental crust formation processes. Thus, in the Porto Nacional-Ipueiras domain, different

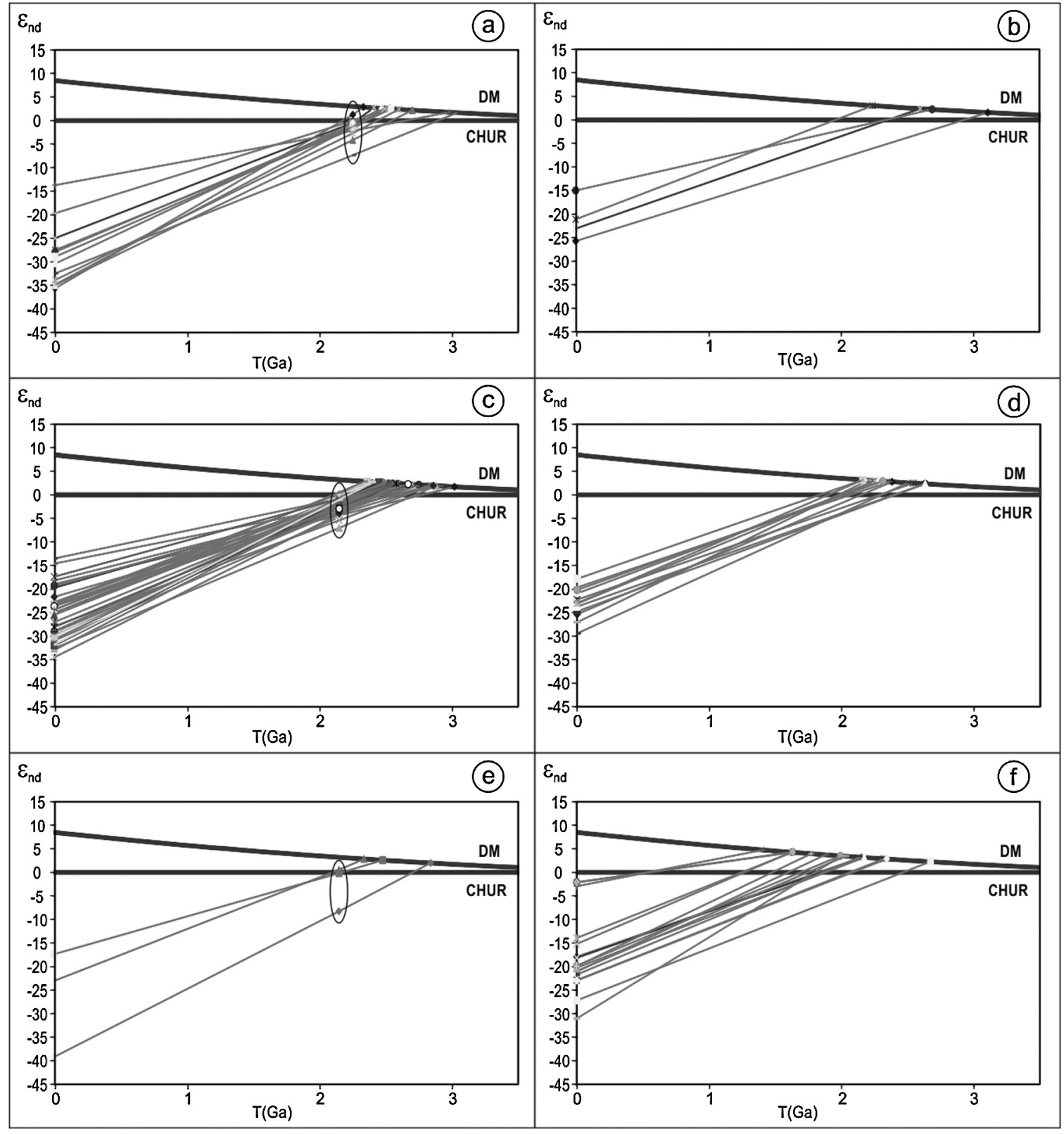

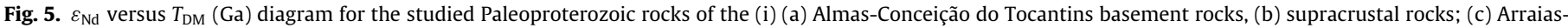

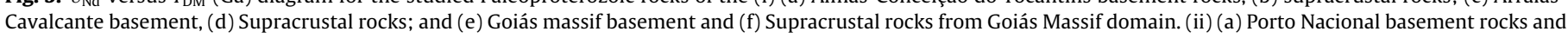
(b) supracrustal sedimentary rocks; (c) Arco Magmatic of Goias basement and (d) Supracrustal rocks. 


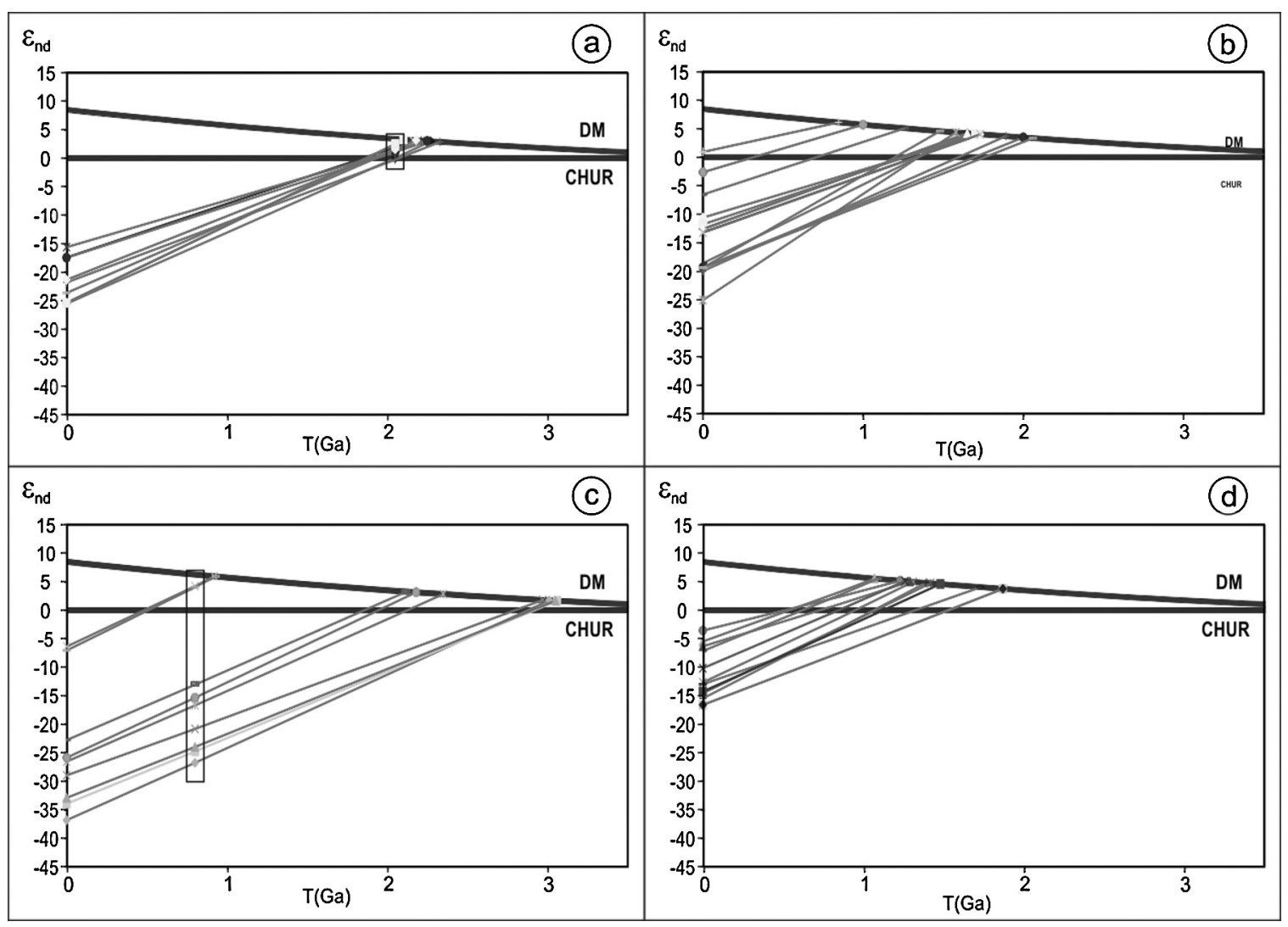

Fig. 5. (Continued).

episodes of crustal growth are present and their understanding requires further investigation.

\section{Discussion}

\subsection{Geodynamic implications and global correlations}

Large cratonic blocks are missing in the Columbia Supercontinent model. These are represented by fragments exposed as basement inliers within younger orogenic belts (Zhao et al., 2006; Reddy and Evans, 2009). Generally, the global connections between pairs of cratons are based on the abundances of isotopic ages for deformation, plutonism and juvenile isotopic signatures. These point to periods of enhanced tectonism at 2.1 until $1.8 \mathrm{Ga}$ during the building of the Paleoproterozoic supercontinent (Evans and Mitchell, 2011). On the other hand, Condie and Aster (2010) suggest that orogenic plutonism age peaks reflect episodicity of the subduction system on local or regional scales, but not on continental scale. In this case, orogenic granitoids are the main source of data for crust formation events in the Paleoproterozoic supercontinent cycles.

The recognition of large crustal Paleoproterozoic fragments in the Tocantins Province is useful for reconstruction models of the assembly of Atlantica. The new U-Pb and Sm-Nd data presented provide new insights in the regional framework of the northern segment of the Tocantins Province, central Brazil, and show that integrated geochronological methods are a useful tool to assess the nature of complex basement areas. The Natividade-Cavalcante crustal block comprises more than $30,000 \mathrm{~km}^{2}$, and constitutes a regenerated basement, integrity and continuity of which was broken by Neoproterozoic orogenic events (Brito Neves, 2011).
The isotopic and geochronological data for the basement exposed in the northern part of the Brasília Belt points to a complex geological history during the Paleoproterozoic.

\subsection{Ga continental crustal growth event}

Identification of rocks formed at c. 2.3-2.4 Ga in the Conceição do Tocantins-Natividade area is relevant, since it can be used as an element of correlation and global models of supercontinents. Rocks formed during this time interval are not very common and this time span has been considered frequently as a period of magmatic quiescence, cooling and cratonization of a supercontinent (Condie, 1994). However, in recent years, magmatic activity at c. 2.3 Ga has been recorded in several continents. Examples are from Laurentia, Canada (Hartlaub et al., 2007), Africa (Gasquet et al., 2003), as well as Russia and Finland. Two occurrences were also reported from Brazil. Orthogneisses dated at 2.3-2.4Ga are the basement of the Brasiliano fold belt in the Médio Coreaú domain, NW Ceará, Borborema Province (Fetter et al., 2000; Santos et al., 2009), suggesting some kind of connection between Tocantins and Borborema provinces, which mean link could be the Transbrasiliano lineament.

Also, orthogneiss and supracrustal rocks dated between c. 2.22 and $2.44 \mathrm{Ga}$ occur in the Iriri-Xingu and Bacajá areas of the Amazônia Central province in the Amazonian Craton (Vasquez et al., 2008). Despite the limited knowledge, it can be suggested as a working hypothesis that these terrains where linked somehow in the past, and related to a single crust forming event.

So far no crust segments of Archean age have been identified in the northeastern basement of the Brasília Belt. However, many of the analyzed orthogneiss samples display $T_{\mathrm{DM}}$ model ages older than $2.5 \mathrm{Ga}$, suggesting that recycling of older continental crust material was involved in the building of Paleoproterozoic crust. 


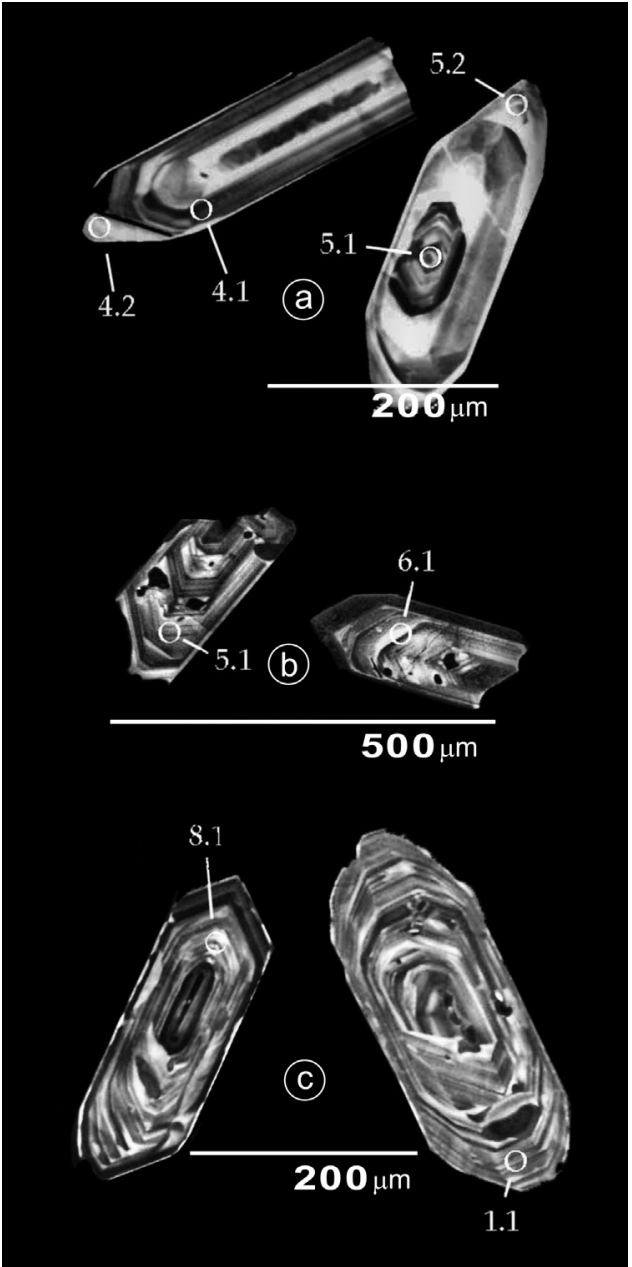

Fig. 6. Cathodoluminescence and back scattering images of igneous zircons from the sample SVAL 2 (a), PNAC 3 (b) and NAT 8 (c). Number of analysis are indicated in the figure. We analyzed border and rim of zircons and all shows igneous structure.

\subsection{Main magmatic event $2.15-2.2 \mathrm{Ga}$}

The main magmatic event in the Natividade-Cavalcante crustal block is concentrated in the relatively short time interval between 2.2 and $2.15 \mathrm{Ga}$. This same time frame appears to bracket the main period of Paleoproterozoic crust formation in the South American continent as a whole (Cordani et al., 2000).

Apparently most of the original granitoid magmas of the studied crustal block were generated by recycling of older continental crust, as inferred from the Nd isotopic evidence. This is particularly the case of the peraluminous granitoids and orthogneisses of the Aurumina Suite in the Cavalcante-Arraias domain(Botelho et al., 2006; Alvarenga et al., 2007).

To the north of Arraias, calc-alkaline metaluminous granitoids make up most of the Almas-Cavalcante domain. The most striking feature of this domain is the presence of narrow, elongated supracrustal belts wrapped around oval-shaped granite-gneiss domes (Cruz and Kuyumjian, 1996, 1998; Cruz et al., 2003). The main crust-forming event was dated at $2.2 \mathrm{Ga}$, as recorded in two calc-alkaline granitoid suites (Cruz and Kuyumjian, 1998; Cruz, 2001; Cruz et al., 2003; Kuyumjian et al., 2012). Age of the supracrustal belts is not well constrained, although preliminary results indicate that they also formed around 2.2 Ga (Dardenne et al., 2009). According to our data, an early Paleoproterozoic event, which took place between 2.3 and $2.4 \mathrm{Ga}$, is recorded in the Natividade-Conceição do Tocantins area, corroborating preliminary data of Cruz (2001) and Cruz et al. (2003).

A younger event took place at c. $2.15-2.18 \mathrm{Ga}$, particularly in the western part of the crustal block. It is also represented by calcalkaline metaluminous granitoids. Part of these Paleoproterozoic rocks displays juvenile isotopic signature, although recycling of older crust material is also recognized in older $T_{\mathrm{DM}}$ model ages and negative $\varepsilon_{\mathrm{Nd}}(t)$ values in several of the analyzed samples. This magmatic event is largely of crustal origin, apparently involving recycling of late Archean crust, with minor addition of juvenile material.

\subsection{Late Paleoproterozoic $2.0-1.77 \mathrm{Ga}$}

Approximately during $2.0 \mathrm{Ga}$, a late peraluminous magmatism took place in the Paranã and Natividade area and also in the Jaú area. Extent and meaning of this late event are not well constrained and, therefore, not well understood.

The late Paleoproterozoic (c. $1.77 \mathrm{Ga}$, Pimentel et al., 1991; Pimentel and Botelho, 2001) Araí and Natividade groups, with basal bimodal volcanic rocks and continental rift sedimentary deposits, which grade upwards into thick marine siliciclastic and minor carbonate rocks, cover the Paleoproterozoic gneiss rocks of the Cavalcante-Natividade crustal block. C. 1.7 Ga fluvio-deltaic and marine sediments, associated with bimodal volcanics and intrusions in the Serra do Espinhaço, central São Francisco Craton and Araçuaí belt, Mantiqueira Province (ref), in the Orós-Jaguaribe belt, Borborema Province (Sá et al., 1991) as well as in Africa are considered as good correlation elements for supercontinent models (Ledru et al., 1994; Brito Neves et al., 2000).

\section{Conclusions}

The few hypothetic connections proposed between cratons in South America do not include the Paleoproterozoic NatividadeCavalcante crust fragment in central Brazil (Cordani, Evans etc.). Models also suggesting amalgamation of different crustal blocks within the Tocantins Province are derived from Nd isotopes (Fuck et al., 2001), which indicate the presence of several domains with different isotopic signatures.

Large shear zones and the presence of granulite complexes associated to thrust belts is referred to as the main evidence of collisional suture zones and are considered as the boundaries of different domains. They are associated to geotectonic models based on gravimetric surveys that suggest that the Tocantins Province resulted from collision of different continental blocks, forming a pop-up-type structure (Hasui et al., 1994).

Two Neoproterozoic domains are well individualized by Nd isotopes in this part of the Tocantins Province. The first one is exposed further to the northwest, beyond the narrow strip of Neoproterozoic arc rocks of the Goiás Magmatic Arc which separates it from the Natividade-Cavalcante block. The other, further to the west is another basement block rather poorly exposed in the area close to Porto Nacional. Paleoproterozoic granite-gneiss terrains (Rio dos Mangues complex) and granulite facies rocks (Porto Nacional complex), underlie the southern portion of the Araguaia belt. The Rio dos Mangues complex was dated at 2.05-2.12 Ga (Arcanjo and Moura, 2000), whereas the Porto Nacional complex is c. $2.15 \mathrm{Ga}$ (Gorayeb et al., 1988). Intrusive granites are c. $2.08 \mathrm{Ga}$. Their $\varepsilon_{\mathrm{Nd}}(t)$ signature suggests juvenile contribution (Chaves et al., 2003).

The boundary between the Goiás Magmatic Arc and the Paleoproterozoic crust segments is well marked in a deep seismic refraction experiment that recorded several crustal blocks separated by deep faults, some of which may represent former sutures, suggesting polarity inversion of Neoproterozoic subduction 
zones during orogeny which led to the building of the Tocantins Province and West Gondwana amalgamation (Soares et al., 2006). Tables $1 \mathrm{a}$ and $1 \mathrm{~b}$ summarizes all events recorded in the central Brazil continental crust segment described in this manuscript and several hypotheses can be suggested for future research. The Natividade-Cavalcante block shows different types of magmatism in a long-lived Paleoproterozoic crust forming event in the Tocantins Province, which lasted for more than $300 \mathrm{Ma}$ of continuous and episodic pulses. However, there are still some pending questions about the significance of this crustal fragment and its relationship with other cratonic blocks in South America.

In the first hypothetic scenario, all Paleoproterozoic fragments could be an extension of the São Francisco Craton, based mainly on geophysical data. Gravity data suggest a single coherent plate, encompassing the São Francisco craton and the basement of Brasilia belt (Pereira and Fuck, 2005; Assumpção et al., 2006; Soares et al., 2006; Valeriano et al., 2004). Some features that support this idea is the similarity between the Arai and Espinhaço Paleo- to Mesoproterozoic sedimentary cover and rift related volcanism, and the $1.7 \mathrm{Ga}$ alkaline granite magmatism in both crustal segments. However, other geological evidence seems to point to the contrary. Archean nuclei, aulacogens and a swarm of basic dykes at $1.0 \mathrm{Ga}$ are only present in the São Francisco craton and not in the Tocantins Province. The absence of large occurrences of S-type granite magmatism in the craton, such as represented by the Aurumina suite in the Tocantins Province, is another point of correlation lack.

Another possibility is that the crustal fragments studied here represent the continuity of Goiás Massif block, which is dominantly formed of Archean granite-greenstone terrains (Crixás, Pilar de Goiás, Guarinos, Serra de Santa Rita and Faina) (Jost et al., 2010), and Paleoproterozoic volcanosedimentary sequences (Ticunzal, Botelho et al., 2006; Campinorte, Della Giustina et al., 2009).
Howevwer, there are no geophysical models suggesting such a correlation.

Finally, the Natividade-Cavalcante block could represent an exotic fragment independent of all other Paleoproterozoic crustal segments in central Brazil. The major problem is to loc0ate the boundaries that represent the discontinuity between this block and the other segments, including the São Francisco craton.

In summary, the major conclusions that can be put forward are the following:

a) Three crustal blocks of different ages are evident, characterizing juvenile and reworked continental crust segments at 2.4, 2.2 and $2.0 \mathrm{Ga}$, whereas the major fault zones represent the boundaries of each block.

b) Generation of Early Paleoproterozoic continental crust was the principal event recorded in the basement rocks of the Tocantins Province.

c) Another important result of this study is the first determination of the boundary between the basement rocks and the Neoproterozoic magmatic Arc in the Tocantins state, already identified by Pimentel and Fuck (1992) in the Porangatu-Mara Rosa region.

\section{Acknowledgements}

We would like to thank CNPq for the scholarship and CNPq/MCT (Instituto Nacional de Ciência e Tecnologia - INCT em Estudos Tectônicos - proc. 573713/2008-1) for financing laboratory and field work. We would also like to thank the technical support from the staff of the Geochronological Laboratory of Brasília University.

\section{Appendix A.}


Table 1a

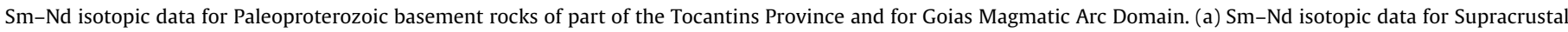
cover and intrusives rocks of part of the Tocantins Province.

\begin{tabular}{|c|c|c|c|c|c|c|c|c|}
\hline Sample & Rock type & $\mathrm{Sm}(\mathrm{ppm})$ & $\mathrm{Nd}(\mathrm{ppm})$ & $147 \mathrm{Sm} / 144 \mathrm{Nd}$ & $143 \mathrm{Nd} / 144 \mathrm{Nd}$ (2sigma) & $T_{\mathrm{DM}}(\mathrm{Ga})$ & $\varepsilon_{\mathrm{Nd}}(0)$ & $\varepsilon_{\mathrm{Nd}}(t)$ \\
\hline \multicolumn{9}{|c|}{ Arraias-Parana Domain } \\
\hline CAB-2 & Granite & 3.35 & 14.08 & 0.1437 & $0.511665(12)$ & 3.02 & -19.98 & -4.45 \\
\hline ARR-1 & Muscovite Granite & 2.95 & 13.34 & 0.1337 & $0.511626(18)$ & 2.70 & -19.74 & -2.46 \\
\hline ARR-2 & Porphyritic Bt Granite & 2.09 & 10.38 & 0.1217 & $0.511438(15)$ & 2.53 & -23.42 & -2.84 \\
\hline ARR-4 & Biotite Granite & 2.92 & 12.96 & 0.1361 & $0.511644(21)$ & 2.75 & -19.40 & -2.77 \\
\hline ARR-5 & Porphyritic Bt Granite & 2.58 & 11.00 & 0.1417 & $0.511706(15)$ & 2.84 & -18.18 & -3.10 \\
\hline ARR-6 & Biotite Granite & 2.59 & 10.40 & 0.1506 & $0.511944(22)$ & 2.66 & -13.54 & -0.90 \\
\hline ARR-9* & Migmatite & 4.29 & 22.94 & 0.1131 & $0.511350(20)$ & 2.56 & -25.12 & -3.13 \\
\hline ARR-10 & Granite & 2.65 & 14.93 & 0.1082 & $0.511353(25)$ & 2.42 & -25.06 & -0.80 \\
\hline ARR-11A & Mafic Migmatite & 2.18 & 14.38 & 0.1017 & $0.511052(24)$ & 2.48 & -30.94 & -4.88 \\
\hline SVAL-1 & Biotite Gneiss & 3.47 & 24.94 & 0.0842 & $0.510948(08)$ & 2.45 & -32.97 & -2.11 \\
\hline NAT-6 & Tonalite & 2.61 & 18.26 & 0.0864 & $0.510869(24)$ & 2.59 & -34.51 & -4.28 \\
\hline NAT-8 & Tonalite gneiss & 4.32 & 26.20 & 0.0996 & $0.511110(24)$ & 2.57 & -29.80 & -3.37 \\
\hline NAT-11 & Aplitic leucogranite & 12.40 & 82.41 & 0.0914 & $0.511065(08)$ & 2.44 & -30.68 & -1.81 \\
\hline NAT-13 & Granite gneiss & 5.06 & 25.52 & 0.1199 & $0.511461(16)$ & 2.56 & -22.95 & -1.90 \\
\hline NAT-14 & Ms Tourmaline Granite & 2.01 & 7.96 & 0.1530 & $0.511889(22)$ & 2.91 & -14.6 & -2.63 \\
\hline PARANÃ-2 & Bt gneiss & 2.516 & 12.898 & 0.1179 & $0.51147(18)$ & 2.49 & -22.71 & -1.17 \\
\hline PARANÃ-5 & Granite & 23.934 & 128.873 & 0.1123 & $0.511453(14)$ & 2.38 & -23.12 & -0.03 \\
\hline PARANÃ- $6^{*}$ & Bt tonalite & 3.145 & 21.341 & 0.0891 & $0.511101(5)$ & 2.36 & -29.98 & -0.49 \\
\hline PARANÃ-7 & Bt granite & 10.457 & 60.829 & 0.1039 & $0.510966(5)$ & 2.88 & -32.61 & -7.09 \\
\hline PARANÃ-8 & Bt gneiss & 3.733 & 19.598 & 0.1151 & $0.511207(7)$ & 2.84 & -27.92 & -5.48 \\
\hline PARANÃ-9 & Bt gneiss & 2.870 & 16.286 & 0.1065 & $0.511251(5)$ & 2.54 & -27.06 & -2.34 \\
\hline PARANÃ-10 & Bt gneiss & 1.898 & 11.686 & 0.0982 & $0.511155(10)$ & 2.48 & -28.93 & -1.82 \\
\hline PARANÃ-11A & Bt granite & 11.729 & 56.977 & 0.1244 & $0.511427(5)$ & 2.76 & -23.63 & -3.74 \\
\hline PARANÃ-11B & Granite & 3.244 & 18.447 & 0.1063 & $0.511385(20)$ & 2.34 & -24.43 & 0.45 \\
\hline PARANÃ-12 & Bt granite & 12.203 & 71.169 & 0.1037 & $0.511144(17)$ & 2.62 & -29.15 & -3.72 \\
\hline PARANÃ-13 & Bt granite & 4.826 & 21.979 & 0.1327 & $0.511528(6)$ & 2.86 & -21.66 & -4.06 \\
\hline PARANÃ-17 & Bt tonalite & 7.158 & 50.515 & 0.0857 & $0.510997(12)$ & 2.45 & -32.40 & -1.90 \\
\hline PARANÃ-18 & Bt granite & 3.418 & 18.716 & 0.1104 & $0.511330(6)$ & 2.52 & -25.51 & -1.85 \\
\hline PARANÃ-19 & Bt gneiss & 3.068 & 13.554 & 0.1368 & $0.511746(7)$ & 2.57 & -17.40 & -0.90 \\
\hline PARANÃ-20 & Bt tonalite & 4.502 & 25.847 & 0.1053 & $0.511198(10)$ & 2.58 & -28.08 & -2.29 \\
\hline PARANÃ-21 & Bt granite & 3.868 & 19.218 & 0.1217 & $0.511426(8)$ & 2.67 & -23.64 & -3.0 \\
\hline PARANÃ-22 & Bt granodiorite & 3.064 & 16.394 & 0.1130 & $0.511388(21)$ & 2.49 & -24.38 & -1.39 \\
\hline PARANÃ-23 & Bt granodiorite & 8.848 & 62.571 & 0.0855 & $0.511009(6)$ & 2.40 & -31.78 & -1.26 \\
\hline \multicolumn{9}{|c|}{ Almas-Conceição Domain } \\
\hline CONTO-1 & Biotite Granite gneiss & 5.50 & 48.22 & 0.0693 & $0.510813(14)$ & 2.33 & -35.61 & +2.43 \\
\hline CONTO-2 & Biotite Granite gneiss & 2.42 & 13.13 & 0.1119 & $0.511358(25)$ & 2.41 & -24.96 & +0.34 \\
\hline CONTO7 & Biotite Granite gneiss & 7.54 & 42.51 & 0.1078 & $0.511229(25)$ & 2.49 & -26.12 & -0.42 \\
\hline CONTO-8 & Granodiorite gneiss & 2.48 & 14.44 & 0.1042 & $0.511209(21)$ & 2.53 & -27.87 & -0.27 \\
\hline CONTO-10 & Fine Amphibolite & 1.82 & 7.02 & 0.1566 & $0.511935(21)$ & 2.98 & -13.74 & -2.72 \\
\hline CONTO- $11^{*}$ & Biotite Granite gneiss & 8.69 & 47.88 & 0.1097 & $0.510975(21)$ & 3.04 & -32.38 & -8.58 \\
\hline CONTO-12 & Biotite Granite gneiss & 5.11 & 24.16 & 0.1288 & $0.511630(12)$ & 2.51 & -19.66 & -1.04 \\
\hline CONTO-13 & Granite gneiss & 8.38 & 54.41 & 0.0936 & $0.511081(14)$ & 2.47 & -30.37 & -2.10 \\
\hline NAT-1 & Biotite granite gneiss & 7.89 & 47.27 & 0.1015 & $0.511157(25)$ & 2.54 & -28.90 & +0.47 \\
\hline NAT-2 & Biotite tonalite & 4.36 & 29.27 & 0.0901 & $0.510848(09)$ & 2.70 & -34.91 & -3.10 \\
\hline NAT-3 & Granite gneiss & 5.88 & 44.35 & 0.0806 & $0.510853(23)$ & 2.49 & -34.82 & -0.17 \\
\hline NAT-4A & Granite gneiss & 2.92 & 19.83 & 0.0889 & $0.510903(12)$ & 2.60 & -33.84 & -1.67 \\
\hline \multicolumn{9}{|c|}{ Porto Nacional Domain } \\
\hline PNAC-1 & Hornblende Granite & 14.19 & 86.20 & 0.0996 & $0.511328(16)$ & 2.27 & -25.55 & +0.06 \\
\hline PNAC-2 & Felsic Volcanic & 7.46 & 36.74 & 0.1233 & $0.511744(19)$ & 2.16 & -17.44 & +1.93 \\
\hline PNAC-3 & Hornblende Granite & 11.87 & 54.42 & 0.1325 & $0.511837(23)$ & 2.23 & -15.62 & +1.32 \\
\hline PN-1a & Hornblende gneiss & 2.49 & 11.96 & 0.1263 & $0.511741(19)$ & 2.25 & -17.49 & +1.08 \\
\hline $\mathrm{PN}-4$ & Hbl Bt Gneiss & 7.17 & 37.76 & 0.1147 & $0.511518(17)$ & 2.33 & -21.85 & \\
\hline FIG-1 & Granite Mylonite & 21.53 & 143.32 & 0.0908 & $0.511335(10)$ & 2.10 & -25.42 & \\
\hline ARAG-1 & Felsic Gneiss & 6.70 & 40.07 & 0.1011 & $0.511423(19)$ & 2.18 & -23.70 & \\
\hline ARAG-2 & Gneiss & 10.89 & 60.01 & 0.1097 & $0.511543(12)$ & 2.18 & -21.36 & \\
\hline POR-21 & Hornblende Granite & 21.53 & 143.32 & 0.0908 & $0.511335(10)$ & 2.10 & -25.41 & \\
\hline \multicolumn{9}{|c|}{ Goais Massif Domain } \\
\hline JAÚ-1 & Bt granite & 1.290 & 7.552 & 0.1032 & $0.511855(8)$ & 1.62 & -15.28 & \\
\hline JAÚ-2 & Bt granite & 0.570 & 3.142 & 0.1097 & $0.511919(9)$ & 1.63 & -14.02 & \\
\hline JAÚ-3 & Syenite & 0.341 & 1.954 & 0.1056 & $0.511617(17)$ & 1.99 & -19.91 & \\
\hline JAÚ-4 & Syenite & 0.129 & 0.850 & 0.0918 & $0.511612(38)$ & 1.77 & -20.02 & \\
\hline JAÚ-5 & Bt granite & 42.188 & 271.262 & 0.0940 & $0.511552(7)$ & 1.88 & -21.18 & \\
\hline JAÚ-6 & Bt gneiss & 6.257 & 35.531 & 0.1065 & $0.511559(13)$ & 2.03 & -20.26 & \\
\hline PARANÃ-16 & Metabasite & 0.029 & 0.103 & 0.1728 & $0.512529(23)$ & 1.63 & -0.83 & \\
\hline PNAC- $4 *$ & Tonalite & 5.65 & 40.47 & 0.0844 & $0.510627(23)$ & 2.84 & -39.23 & -9.71 \\
\hline SVAL-2 & Tonalite gneiss & 5.50 & 24.74 & 0.1343 & $0.511746(14)$ & 2.48 & -17.41 & -0.16 \\
\hline \multicolumn{9}{|c|}{ Goiás Magmatic Arc } \\
\hline LIS-39A & $\mathrm{Hb}$ bt gneiss & 15.18 & 98.48 & 0.0932 & $0.512311(16)$ & 0.92 & -6.37 & \\
\hline LIS-39B & $\mathrm{Hb}$ diorite & 21.311 & 128.892 & 0.0999 & $0.511276(15)$ & 2.35 & -26.57 & \\
\hline LIS-39C & Gneiss & 17.846 & 115.467 & 0.0934 & $0.511311(16)$ & 2.18 & -25.89 & \\
\hline LIS-40 & Bt granite & 12.71 & 65.94 & 0.1165 & $0.512533(11)$ & 0.80 & -2.04 & \\
\hline LIS-41 & Bt granite & 20.946 & 124.802 & 0.1015 & $0.511470(13)$ & 2.12 & -22.77 & \\
\hline LIS-43 & Anortosite & 24.01 & 16.484 & 0.0881 & $0.512276(22)$ & 0.93 & -7.06 & \\
\hline LIS-47 & Gneiss & 27.04 & 16.771 & 0.0975 & $0.510748(19)$ & 3.01 & -36.87 & \\
\hline LIS-49A & Tonalite & 35.21 & 19.973 & 0.1066 & $0.510897(21)$ & 3.06 & -33.96 & \\
\hline LIS-49B & Granite & 33.08 & 18.387 & 0.1088 & $0.510949(8)$ & 3.05 & -32.96 & \\
\hline LIS-49C & Leucogranite & 0.988 & 51.19 & 0.1166 & $0.511152(20)$ & 2.97 & -28.98 & \\
\hline
\end{tabular}

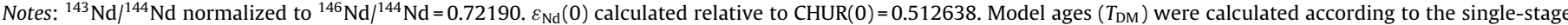

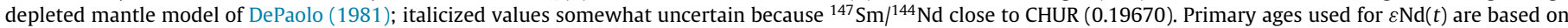
$\mathrm{U} / \mathrm{Pb}$ ages where known or estimated based on regional geology.

* $2.15 \mathrm{Ga}$ for Arraias Domain.

** 2.05 Ga for Porto Nacional Domain.

*** $2.3 \mathrm{Ga}$ for Almas Conceição Domain. Details in the text.

Where we did not calculate $\varepsilon_{\mathrm{Nd}}(t)$ values, because it does not have knowledge on ages. 
Table 1b

Sm-Nd isotopic data for Supracrustal cover and intrusives rocks of part of the Tocantins Province.

\begin{tabular}{|c|c|c|c|c|c|c|c|c|}
\hline Sample & Rock type & $\mathrm{Sm}(\mathrm{ppm})$ & $\mathrm{Nd}(\mathrm{ppm})$ & $147 \mathrm{Sm} / 144 \mathrm{Nd}$ & $143 \mathrm{Nd} / 144 \mathrm{Nd}$ (2sigma) & $T_{\mathrm{DM}}(\mathrm{Ga})$ & $\varepsilon_{\mathrm{Nd}}(0)$ & $\varepsilon_{\mathrm{Nd}}(t)$ \\
\hline \multicolumn{9}{|c|}{ Arraias-Parana Domain } \\
\hline ARR-7 & Metasediment & 20.65 & 118.79 & 0.1051 & $0.511338(07)$ & 2.38 & -25.35 & \\
\hline ARR-11B & Amphibolite (xenolith) & 1.67 & 5.22 & 0.1929 & $0.512647(19)$ & - & +0.17 & \\
\hline ARR-12 & Hornblendite & 4.85 & 24.18 & 0.1218 & $0.511496(12)$ & 2.54 & -22.28 & \\
\hline NAT-12 & Muscovite Schist & 2.78 & 14.38 & 0.1174 & $0.511369(23)$ & 2.63 & -24.75 & \\
\hline PARANÃ-3 & Bt schist & 4.355 & 21.365 & 0.1232 & $0.51163(12)$ & 2.36 & -19.61 & \\
\hline PARANÃ-4 & Bt-Ms schist & 13.202 & 81.932 & 0.0974 & $0.51113(5)$ & 2.50 & -29.51 & \\
\hline PARANÃ-14 & Schist & 1.279 & 8.534 & 0.0906 & $0.51125(11)$ & 2.20 & -27.05 & \\
\hline LIS-1 & Quartzite & 0.422 & 2.21 & 0.1156 & $0.511565(16)$ & 2.28 & -20.92 & \\
\hline LIS-3 & Schist & 8.566 & 42.637 & 0.1215 & $0.511723(13)$ & 2.16 & -17.85 & \\
\hline LIS-4 & Schist & 4 & 18 & 0.1199 & $0.511421(14)$ & 2.63 & -23.74 & \\
\hline LIS-8 & Quartzite & 0.488 & 2.77 & 0.1065 & $0.511453(13)$ & 2.25 & -23.12 & \\
\hline LIS-9 & Quartzite & 2.264 & 13.285 & 0.103 & $0.511459(24)$ & 2.16 & -22.99 & \\
\hline LIS-17 & Quartzite & 2.166 & 10.992 & 0.1191 & $0.511603(7)$ & 2.31 & -20.18 & \\
\hline LIS-18 & Phylitte & 52.82 & 28.166 & 0.1134 & $0.511664(11)$ & 2.08 & -18.99 & \\
\hline LIS-19 & Phyitte & 84.29 & 47.005 & 0.1084 & $0.511684(12)$ & 1.95 & -18.60 & \\
\hline LIS-20 & Gneiss & 56.11 & 32.111 & 0.1056 & $0.511624(12)$ & 1.98 & -19.78 & \\
\hline \multicolumn{9}{|c|}{ Almas-Conceição Domain } \\
\hline NAT-5 & Quartzite & 0.95 & 4.45 & 0.1290 & $0.511323(08)$ & 3.11 & -25.65 & \\
\hline CONTO-4 & $\mathrm{BIF}$ & 0.81 & 4.03 & 0.1210 & $0.511458(20)$ & 2.60 & -23.02 & \\
\hline CONTO-5 & Metavolcanic & 5.65 & 30.11 & 0.1134 & $0.511560(17)$ & 2.24 & -21.04 & \\
\hline CONTO-9A & Amfibolite & 3.92 & 16.09 & 0.1481 & $0.511872(22)$ & 2.69 & -14.94 & \\
\hline \multicolumn{9}{|c|}{ Porto Nacional Domain } \\
\hline GUR-1a & Biotite Gneiss & 6.47 & 33.17 & 0.1179 & $0.511994(16)$ & 1.65 & -12.56 & \\
\hline STR-2 & Garnet Biotite gneiss & 1.44 & 7.28 & 0.1198 & $0.511963(15)$ & 1.73 & -13.16 & \\
\hline GUR-2 & Biotite Schist & 11.19 & 32.41 & 0.2087 & $0.511982(33)$ & - & -12.80 & \\
\hline $\mathrm{PN}-2 \mathrm{C}$ & Hornblende Granite & 15.35 & 85.68 & 0.1083 & $0.511649(20)$ & 2.00 & -19.28 & \\
\hline $\mathrm{PN}-3$ & Granite Mylonite & 0.95 & 5.75 & 0.0993 & $0.511615(11)$ & 1.89 & -19.90 & \\
\hline BREJ-1 & Granulite & 11.17 & 75.36 & 0.0896 & $0.511685(10)$ & 1.65 & -18.59 & \\
\hline BREJ-2 & Biotite Granite & 1.77 & 9.63 & 0.1110 & $0.511644(14)$ & 2.06 & -19.39 & \\
\hline BREJ-3 & Granite & 6.65 & 30.57 & 0.1314 & $0.512095(18)$ & 1.73 & -10.59 & \\
\hline BREJ-4 & Biotite Granite & 45.99 & 223.31 & 0.1245 & $0.512035(16)$ & 1.70 & -11.76 & \\
\hline GUR-1a & Biotite Gneiss & 6.47 & 33.17 & 0.1179 & $0.511994(16)$ & 1.65 & -12.56 & \\
\hline STR-2 & Garnet Biotite gneiss & 1.44 & 7.28 & 0.1198 & $0.511963(15)$ & 1.73 & -13.16 & \\
\hline FAT-1 & Granodiorite Gneiss & 11.84 & 137.09 & 0.0522 & $0.511352(23)$ & 1.58 & -25.08 & \\
\hline QUIX-1 & Granite & 4.98 & 22.70 & 0.1326 & $0.512504(14)$ & 1.00 & -2.61 & \\
\hline ALVO-1 & Gabbro Gneiss & 5.54 & 22.46 & 0.1492 & $0.512687(09)$ & 0.84 & +0.95 & \\
\hline ALVO-2 & $\mathrm{Hb}$ Bt Gneiss & 12.36 & 59.72 & 0.1251 & $0.512304(05)$ & 1.26 & -6.51 & \\
\hline $\mathrm{PN}-2 \mathrm{~b}$ & Biotite Granite & 10.93 & 92.95 & 0.0711 & $0.511645(09)$ & 1.48 & -19.36 & \\
\hline \multicolumn{9}{|c|}{ Goais Massif Domain } \\
\hline PALMERO-2 & Marble & 0.720 & 3.622 & 0.1201 & $0.511715(10)$ & 2.15 & -18.01 & \\
\hline PALMERO-3 & Schist & 4.459 & 22.392 & 0.1204 & $0.511704(15)$ & 2.17 & -18.23 & \\
\hline PALMERO-4 & Bt Schist & 5.091 & 27.891 & 0.1103 & $0.511459(11)$ & 2.32 & -23.00 & \\
\hline PARANÃ-16 & Metabasite & 0.029 & 0.103 & 0.1728 & $0.512529(23)$ & 1.63 & -0.83 & \\
\hline LIS-25 & Marble & 3.214 & 12.611 & 0.1541 & $0.512485(25)$ & 1.41 & -2.99 & \\
\hline LIS-29 & Garnet Schist & 4 & 25 & 0.106 & $0.511520(9)$ & 2.14 & -21.81 & \\
\hline LIS-30 & Quartzite & 1.418 & 13.769 & 0.0622 & $0.511039(20)$ & 2.00 & -31.18 & \\
\hline LIS-32 & Biotite granite & 20.195 & 109.937 & 0.1111 & $0.511455(12)$ & 2.34 & -23.09 & \\
\hline LIS-34 & Quartzite & 2.562 & 13.983 & 0.1108 & $0.511237(19)$ & 2.67 & -27.34 & \\
\hline LIS-36 & Schist & 3.533 & 18.919 & 0.1129 & $0.511596(6)$ & 2.17 & -20.32 & \\
\hline \multicolumn{9}{|c|}{ Goiás Magmatic Arc } \\
\hline LIS-57 & Schist & 11.616 & 62.488 & 0.1124 & $0.511785(11)$ & 1.87 & -16.63 & \\
\hline LIS-51 & Gneiss & 1.667 & 8.62 & 0.1169 & $0.512356(11)$ & 1.07 & -5.51 & \\
\hline LIS-52A & Gneiss & 1.544 & 10.104 & 0.0924 & $0.511987(22)$ & 1.31 & -12.71 & \\
\hline LIS-52B & Gneiss & 2.948 & 19.515 & 0.0913 & $0.511891(7)$ & 1.42 & -14.57 & \\
\hline LIS-53 & Gneiss & 1.277 & 54.438 & 0.1418 & $0.512454(7)$ & 1.23 & -3.59 & \\
\hline LIS-55 & Gneiss & 5.299 & 38.419 & 0.0834 & $0.511844(25)$ & 1.39 & -15.49 & \\
\hline LIS-55 A & Gneiss & 2.197 & 12.457 & 0.1066 & $0.512271(18)$ & 1.09 & -7.17 & \\
\hline LIS-56 & Tonalite & 7.036 & 35.316 & 0.1204 & $0.511971(17)$ & 1.73 & -13.02 & \\
\hline LIS-57 & Schist & 11.616 & 62.488 & 0.1124 & $0.511785(11)$ & 1.87 & -16.63 & \\
\hline LIS-58 & Tonalite & 5.464 & 33.817 & 0.0977 & $0.511905(10)$ & 1.48 & -14.29 & \\
\hline NAT-9A* & Tonalite gneiss & 9.13 & 42.93 & 0.1286 & $0.512312(13)$ & 1.29 & -6.36 & +1.05 \\
\hline NAT-9B ${ }^{*}$ & Granite & 1.48 & 8.75 & 0.1026 & $0.512116(20)$ & 1.26 & -10.19 & +0.05 \\
\hline
\end{tabular}

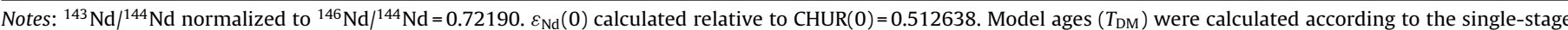

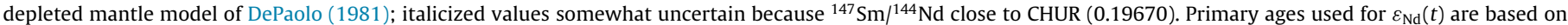
$\mathrm{U} / \mathrm{Pb}$ ages where known.

${ }^{*} t=850 \mathrm{Ma}$ or not calculated due are rocks young than Paleoproterozoic age. 
Table 2

Sumary for U-Pb TIMS data.

\begin{tabular}{|c|c|c|c|c|c|c|c|c|c|c|c|c|c|c|}
\hline Sample Fraction & Size (mg) & U ppm & Pbppm & $\begin{array}{l}\mathrm{Pb} 206 \\
\text { Pb204 } \\
\text { (obs.) }\end{array}$ & $\begin{array}{l}\mathrm{Pb} 207^{*} \\
\mathrm{U} 235\end{array}$ & (pct) & $\mathrm{Pb} 206 * \mathrm{U} 238$ & (pct) & $\begin{array}{l}\text { Correl. } \\
\text { Coeff. (rho) }\end{array}$ & $\begin{array}{l}\text { Pb207* } \\
\text { Pb206* }\end{array}$ & (pct) & $\begin{array}{l}\text { Pb206* } \\
\text { U238 Age }\end{array}$ & $\begin{array}{l}\text { Pb207* } \\
\text { U235 Age }\end{array}$ & $\begin{array}{l}\mathrm{Pb} 207^{*} \\
\text { Pb206* Age } \\
\text { (ma) }\end{array}$ \\
\hline Conto $6 \mathrm{~S}$ & 0.014 & 260 & 148 & 275 & 9.03747 & 1.69 & 0.426915 & 1.57 & 0.932 & 0.153412 & 0.932 & 2290 & 2340 & 2384 \\
\hline Contop 614 & 0.021 & 129 & 57 & 1662 & 8.00552 & 0.56 & 0.387133 & 0.52 & 0.922 & 0.149978 & 0.22 & 2109 & 2231 & 2345 \\
\hline Conto 613 & 0.016 & 165 & 75 & 1065 & 8.287808 & 0.76 & 0.398564 & 0.76 & 0.989 & 0.1508 & 0.109 & 2162 & 2262 & 2355 \\
\hline Conto $11 \mathrm{~L}$ & 0.022 & 484 & 121 & 807 & 3.88243 & 1.09 & 0.214068 & 1.09 & 0.997 & 0.131538 & 0.079 & 1250 & 1610 & 2118 \\
\hline Conto 1118 & 0.033 & 343 & 95 & 242 & 3.44303 & 0.705 & 0.200697 & 0.632 & 0.899 & 0.124423 & 0.308 & 1179 & 1514 & 2020 \\
\hline Conto-11 6 & 0.013 & 25.038 & 10.783 & 6926 & 6.43486 & 0.687 & 0.352242 & 0.664 & 0.967899 & 0.132494 & 0.173 & 1945 & 2037 & 2131 \\
\hline Conto-119 & 0.014 & 11.069 & 26.341 & 6020 & 6.1613 & 0.675 & 0.339111 & 0.645 & 0.958039 & 0.131774 & 0.193 & 1882 & 1999 & 2122 \\
\hline Nat $2 \mathrm{G}$ & 0.036 & 279 & 91 & 2129 & 5.5421 & 1.02 & 0.288039 & 1.02 & 0.996 & 0.142896 & 0.09 & 1637 & 1931 & 2262 \\
\hline Nat $2 \mathrm{~F}$ & 0.024 & 159 & 58 & 205 & 4.77669 & 1.46 & 0.25828 & 1.35 & 0.929 & 0.140607 & 0.54 & 1472 & 1814 & 2234 \\
\hline Nat $2 \mathrm{~J}$ & 0.018 & 150 & 40 & 884 & 4.16985 & 1.22 & 0.231761 & 1.2 & 0.981 & 0.138728 & 0.23 & 1355 & 1726 & 2211 \\
\hline Nat 25 & 0.014 & 490 & 153 & 1280 & 4.98254 & 1.19 & 0.267358 & 1.17 & 0.98419 & 0.138664 & 0.211 & 1531 & 1840 & 2210 \\
\hline Nat2 Y & 0.009 & 213 & 62 & 1036 & 4.67699 & 1.37 & 0.252075 & 1.36 & 0.994 & 0.134566 & 0.148 & 1449 & 1763 & 2158 \\
\hline Nata $2 \mathrm{~W}$ & 0.008 & 191 & 66 & 457 & 5.87918 & 1.73 & 0.299512 & 1.71 & 0.9872 & 0.142364 & 0.275 & 1688 & 1958 & 2256 \\
\hline Arraias $5 \mathrm{U}$ & 0.034 & 293 & 82 & 1290 & 4.66487 & 0.97 & 0.260569 & 0.97 & 0.997 & 0.129842 & 0.069 & 1492 & 1761 & 2095 \\
\hline Arraias 5 B & 0.034 & 286 & 98 & 516 & 5.43149 & 1.13 & 0.300277 & 1.11 & 0.989 & 0.131188 & 0.164 & 1692 & 1889 & 2113 \\
\hline Arraias 511 & 0.05 & 184 & 67 & 2103 & 6.33374 & 1.04 & 0.347833 & 1.04 & 0.996 & 0.132065 & 0.09 & 1924 & 2023 & 2125 \\
\hline Arraias 9 J & 0.012 & 378 & 91 & 378 & 3.55295 & 1.1 & 0.213515 & 0.825 & 0.8113 & 0.120687 & 0.643 & 1247 & 1539 & 1966 \\
\hline Arraias $9 \mathrm{~T}$ & 0.008 & 402 & 78 & 648 & 3.12736 & 1.55 & 0.190649 & 1.54 & 0.99 & 0.118971 & 0.217 & 1124 & 1439 & 1940 \\
\hline Arraias 919 & 0.006 & 134 & 47 & 205 & 5.24832 & 3.17 & 0.305576 & 3.04 & 0.968 & 0.124566 & 0.798 & 1718 & 1860 & 2022 \\
\hline Paranã 12 B & 0.035 & 197.5 & 7.8524 & 7728 & 6.80576 & 0.288 & 0.368078 & 0.286 & 0.99444447 & 0.134102 & 0.0303 & 2.0204 & 2.0865 & 2.1524 \\
\hline Paranã 12 C & 0.02 & 1449 & 6.2923 & 2973 & 7.39568 & 0.382 & 0.396457 & 0.375 & 0.982518 & 0.135295 & 0.0711 & 2.1527 & 2.1604 & 2.1678 \\
\hline Paranã $12 \mathrm{E}$ & 0.006 & 2197 & 9.0008 & 1019 & 7.11816 & 0.953 & 0.38614 & 0.867 & 0.909349 & 0.133697 & 0.397 & 2.1049 & 2.1263 & 2.1471 \\
\hline
\end{tabular}

Notes:

All samples were nonmagnetic fractions on Frantz separator at $1.5 \AA$ power; $\mathrm{e}=$ hand-picked elongate to euhedral grains; $\mathrm{L}=$ elongate grains; $\mathrm{S}=\mathrm{stubby} ; \mathrm{s}=\mathrm{single}$ grain; $\mathrm{m}=\mathrm{multiple}$ grains

First sample number $=\mathrm{ID} \#$ of grain. $\mathrm{p}=$ prismatic grain, $\mathrm{c}=$ clear, $\mathrm{r}=\mathrm{red}, \mathrm{h}=$ honey color.

Total $\mathrm{U}$ and $\mathrm{Pb}$ concentrations corrected for analytical blank.

Observed 206 $\mathrm{Pb} / 204 \mathrm{~Pb}$ not corrected for blank or non-radiogenic $\mathrm{Pb}$.

Radiogenic Pb corrected for blank and initial Pb: $U$ corrected for blank.

Ages given in Ma using decay constants recommended by Steiger and Jager (1977). 
Table 3

Summary of ICP-MS U-Pb zircon data.

\begin{tabular}{|c|c|c|c|c|c|c|c|c|c|c|c|c|c|c|c|c|c|}
\hline Sample & $f(206) \%$ & $\mathrm{Th} / \mathrm{U}$ & $6 / 4$ ratio & $7 / 6$ ratio & $1 \mathrm{~s}(\%)$ & $7 / 5$ ratio & $1 \mathrm{~s}(\%)$ & $6 / 8$ ratio & $1 \mathrm{~s}(\%)$ & Rho & $7 / 6$ age & $1 \mathrm{~s}(\%)$ & $7 / 5$ age & $1 \mathrm{~s}(\%)$ & $6 / 8$ age & $1 \mathrm{~s}(\%)$ & Conc (\%) \\
\hline \multicolumn{18}{|c|}{ Sample JAÚ 6} \\
\hline $040 \mathrm{Z32}$ & 0.68 & 0.14 & 2591 & 0.087 & 4.8 & 1.350 & 12.3 & 0.112 & 11.2 & 0.97 & 1363.6 & 89.4 & 867.4 & 69.1 & 686.3 & 73.1 & 50.33 \\
\hline 024 Z18 & 0.21 & 0.02 & 15,013 & 0.094 & 1.3 & 1.968 & 2.3 & 0.153 & 1.9 & 0.82 & 1498.3 & 23.9 & 1104.6 & 15.2 & 915.7 & 16.1 & 61.11 \\
\hline 006 Z04 & 0.06 & 0.10 & 26,152 & 0.099 & 2.5 & 2.418 & 3.2 & 0.177 & 2.0 & 0.76 & 1601.3 & 45.6 & 1247.8 & 22.9 & 1053.3 & 19.9 & 65.78 \\
\hline 009 Z07 & 0.03 & 0.12 & 49,882 & 0.109 & 1.4 & 2.845 & 3.4 & 0.189 & 3.1 & 0.91 & 1788.6 & 24.9 & 1367.6 & 25.3 & 1114.5 & 31.9 & 62.31 \\
\hline $036 \mathrm{Z2} 2$ & 0.02 & 0.13 & 66,405 & 0.107 & 3.1 & 3.844 & 6.2 & 0.262 & 5.3 & 0.94 & 1741.0 & 56.3 & 1602.0 & 48.7 & 1498.5 & 71.0 & 86.07 \\
\hline $010 \mathrm{Z08}$ & 0.02 & 0.10 & 78,105 & 0.111 & 2.3 & 4.214 & 3.5 & 0.274 & 2.6 & 0.83 & 1821.5 & 41.7 & 1676.8 & 28.0 & 1563.6 & 35.4 & 85.84 \\
\hline 025 Z19 & 0.05 & 0.15 & 34,836 & 0.123 & 1.3 & 4.588 & 2.6 & 0.271 & 2.3 & 0.87 & 1994.9 & 22.3 & 1747.0 & 21.3 & 1547.5 & 30.9 & 77.57 \\
\hline 037 Z29 & 0.02 & 0.18 & 95,378 & 0.127 & 1.9 & 4.752 & 3.5 & 0.271 & 3.0 & 0.84 & 2057.7 & 32.9 & 1776.4 & 29.0 & 1547.0 & 40.5 & 75.18 \\
\hline 038 Z30 & 0.01 & 0.19 & 167,855 & 0.113 & 0.9 & 4.794 & 1.7 & 0.309 & 1.4 & 0.85 & 1842.5 & 15.6 & 1783.9 & 14.0 & 1734.3 & 21.9 & 94.13 \\
\hline 007 Z05 & 0.03 & 0.09 & 60,219 & 0.118 & 0.7 & 4.953 & 1.4 & 0.305 & 1.2 & 0.86 & 1920.4 & 12.2 & 1811.3 & 11.5 & 1718.0 & 17.9 & 89.46 \\
\hline 027 Z21 & 0.08 & 0.28 & 18,676 & 0.119 & 0.9 & 4.953 & 1.8 & 0.301 & 1.6 & 0.88 & 1945.4 & 15.1 & 1811.4 & 15.1 & 1697.2 & 23.6 & 87.24 \\
\hline $028 \mathrm{Z} 22$ & 0.04 & 0.18 & 66,228 & 0.123 & 0.9 & 4.984 & 1.8 & 0.294 & 1.6 & 0.86 & 2001.8 & 16.1 & 1816.7 & 15.4 & 1659.7 & 23.2 & 82.91 \\
\hline 034 Z26 & 0.02 & 0.07 & 89,431 & 0.115 & 0.9 & 5.050 & 1.9 & 0.320 & 1.7 & 0.88 & 1872.3 & 15.7 & 1827.7 & 16.0 & 1788.8 & 26.3 & 95.54 \\
\hline 004 Z02 & 0.02 & 0.05 & 235,659 & 0.126 & 1.4 & 5.101 & 2.5 & 0.294 & 2.1 & 0.83 & 2040.6 & 23.9 & 1836.3 & 20.8 & 1661.6 & 30.2 & 81.43 \\
\hline $035 \mathrm{Z27}$ & 0.02 & 0.05 & 81,017 & 0.115 & 1.1 & 5.170 & 1.9 & 0.325 & 1.5 & 0.79 & 1885.9 & 20.4 & 1847.7 & 15.8 & 1814.0 & 23.3 & 96.19 \\
\hline 016 Z12 & 0.02 & 0.24 & 81,428 & 0.116 & 1.5 & 5.378 & 2.5 & 0.335 & 2.1 & 0.82 & 1902.3 & 26.0 & 1881.4 & 21.4 & 1862.5 & 33.2 & 97.91 \\
\hline 019 Z15 & 0.05 & 0.16 & 31,600 & 0.127 & 1.2 & 5.599 & 2.3 & 0.319 & 2.0 & 0.85 & 2059.9 & 21.2 & 1915.9 & 19.9 & 1785.8 & 31.0 & 86.69 \\
\hline $030 \mathrm{Z2} 4$ & 0.06 & 0.35 & 25,855 & 0.120 & 1.6 & 5.868 & 2.5 & 0.355 & 1.9 & 0.79 & 1956.2 & 28.7 & 1956.5 & 21.4 & 1956.7 & 31.9 & 100.02 \\
\hline 017 Z13 & 0.04 & 0.14 & 43,650 & 0.127 & 0.8 & 5.876 & 1.8 & 0.335 & 1.6 & 0.89 & 2057.5 & 14.0 & 1957.7 & 15.4 & 1864.8 & 26.0 & 90.63 \\
\hline 003 Z01 & 0.02 & 0.15 & 83,843 & 0.125 & 0.7 & 6.180 & 1.4 & 0.358 & 1.2 & 0.87 & 2030.7 & 11.7 & 2001.6 & 12.2 & 1973.6 & 20.9 & 97.19 \\
\hline 008 Z06 & 0.02 & 0.11 & 76,730 & 0.126 & 1.0 & 6.191 & 2.2 & 0.357 & 2.0 & 0.89 & 2037.7 & 17.8 & 2003.2 & 19.1 & 1969.9 & 33.2 & 96.67 \\
\hline 013 Z09 & 0.02 & 0.26 & 66,512 & 0.124 & 0.8 & 6.223 & 1.7 & 0.365 & 1.5 & 0.87 & 2007.8 & 14.2 & 2007.6 & 14.4 & 2007.5 & 25.0 & 99.98 \\
\hline 018 Z14 & 0.04 & 0.21 & 34,527 & 0.127 & 0.9 & 6.252 & 1.9 & 0.358 & 1.7 & 0.87 & 2052.8 & 16.1 & 2011.8 & 16.5 & 1972.1 & 28.2 & 96.07 \\
\hline 039 Z31 & 0.04 & 0.10 & 38,718 & 0.121 & 1.1 & 6.262 & 2.1 & 0.375 & 1.7 & 0.83 & 1974.0 & 20.4 & 2013.1 & 18.1 & 2051.5 & 30.2 & 103.93 \\
\hline 015 Z11 & 0.01 & 0.28 & 112,344 & 0.123 & 1.1 & 6.289 & 2.0 & 0.371 & 1.6 & 0.81 & 2000.9 & 20.3 & 2016.9 & 17.2 & 2032.7 & 27.8 & 101.59 \\
\hline 020 Z16 & 0.01 & 0.27 & 129,042 & 0.122 & 1.6 & 6.362 & 2.4 & 0.378 & 1.8 & 0.78 & 1986.6 & 27.6 & 2027.1 & 21.1 & 2067.0 & 32.4 & 104.05 \\
\hline 026 Z20 & 0.06 & 0.28 & 27,495 & 0.128 & 1.9 & 6.470 & 2.6 & 0.366 & 1.8 & 0.76 & 2076.0 & 32.7 & 2041.8 & 22.8 & 2008.2 & 31.4 & 96.74 \\
\hline 023 Z17 & 0.02 & 0.14 & 69,747 & 0.124 & 0.7 & 6.483 & 1.6 & 0.379 & 1.5 & 0.90 & 2016.2 & 12.5 & 2043.6 & 14.2 & 2071.0 & 25.7 & 102.72 \\
\hline 029 Z23 & 0.11 & 0.12 & 14,290 & 0.128 & 1.3 & 6.522 & 2.4 & 0.371 & 2.1 & 0.84 & 2065.6 & 22.9 & 2048.9 & 21.3 & 2032.3 & 36.0 & 98.39 \\
\hline 033 Z25 & 0.11 & 0.06 & 13,643 & 0.125 & 0.7 & 6.528 & 1.9 & 0.378 & 1.8 & 0.92 & 2030.6 & 13.2 & 2049.7 & 16.9 & 2068.7 & 31.3 & 101.87 \\
\hline 005 Z03 & 0.01 & 0.29 & 176,052 & 0.119 & 1.1 & 6.722 & 2.1 & 0.408 & 1.7 & 0.84 & 1948.0 & 19.6 & 2075.5 & 18.2 & 2206.4 & 32.5 & 113.27 \\
\hline 014 Z10 & 0.04 & 0.28 & 62,146 & 0.122 & 0.9 & 6.847 & 1.9 & 0.407 & 1.6 & 0.87 & 1984.8 & 16.2 & 2091.8 & 16.4 & 2202.3 & 30.2 & 110.96 \\
\hline \multicolumn{18}{|c|}{ Sample PARANÃ 2} \\
\hline $11 \mathrm{Z5}$ & 0.23 & 0.00 & 7640 & 0.085 & 1.0 & 1.760 & 1.3 & 0.150 & 0.7 & 0.56 & 1316.9 & 19.6 & 1030.9 & 8.1 & 901.5 & 6.3 & 87.44 \\
\hline $27 \mathrm{Z13}$ & 0.02 & 0.00 & 97,672 & 0.120 & 0.7 & 4.381 & 1.0 & 0.264 & 0.7 & 0.67 & 1963.4 & 12.6 & 1708.7 & 8.3 & 1508.8 & 9.5 & 88.30 \\
\hline $12 \mathrm{Z} 6$ & 0.03 & 0.00 & 60,122 & 0.122 & 1.8 & 4.472 & 2.4 & 0.267 & 1.7 & 0.79 & 1980.9 & 31.8 & 1725.8 & 20.2 & 1523.3 & 22.4 & 88.27 \\
\hline $07 \mathrm{Z3}$ & 0.04 & 0.00 & 41,777 & 0.132 & 0.9 & 5.883 & 1.5 & 0.324 & 1.2 & 0.80 & 2120.7 & 15.0 & 1958.7 & 12.6 & 1809.2 & 18.6 & 92.37 \\
\hline $43 \mathrm{Z21}$ & 0.01 & 0.00 & 106,186 & 0.131 & 0.7 & 6.291 & 1.0 & 0.347 & 0.7 & 0.70 & 2117.4 & 11.5 & 2017.2 & 8.5 & 1920.8 & 12.0 & 95.22 \\
\hline $16 \mathrm{Z8}$ & 0.05 & 0.00 & 44,931 & 0.133 & 0.9 & 6.620 & 1.3 & 0.361 & 0.9 & 0.69 & 2138.5 & 16.0 & 2062.0 & 11.5 & 1986.4 & 15.9 & 96.33 \\
\hline $40 \mathrm{Z} 20$ & 0.03 & 0.00 & 43,758 & 0.136 & 0.7 & 7.255 & 1.1 & 0.387 & 0.8 & 0.76 & 2176.5 & 11.5 & 2143.3 & 9.4 & 2108.8 & 14.8 & 98.39 \\
\hline $08 \mathrm{Z4}$ & 0.03 & 0.00 & 50,802 & 0.136 & 0.6 & 7.330 & 0.9 & 0.390 & 0.7 & 0.67 & 2182.0 & 11.1 & 2152.5 & 8.2 & 2121.7 & 11.8 & 98.57 \\
\hline $15 \mathrm{Z7}$ & 0.05 & 0.00 & 30,251 & 0.133 & 1.0 & 7.040 & 1.5 & 0.384 & 1.1 & 0.74 & 2135.9 & 17.3 & 2116.5 & 13.3 & 2096.6 & 20.1 & 99.06 \\
\hline $47 \mathrm{Z} 23$ & 0.03 & 0.00 & 42,656 & 0.136 & 0.7 & 7.407 & 1.1 & 0.394 & 0.8 & 0.72 & 2181.2 & 12.6 & 2161.9 & 9.8 & 2141.6 & 15.0 & 99.06 \\
\hline $28 \mathrm{Z14}$ & 0.03 & 0.00 & 47,367 & 0.137 & 0.7 & 7.489 & 1.1 & 0.397 & 0.8 & 0.72 & 2189.3 & 12.9 & 2171.6 & 9.9 & 2152.9 & 15.1 & 99.14 \\
\hline $23 \mathrm{Z11}$ & 0.03 & 0.00 & 52,920 & 0.135 & 0.9 & 7.278 & 1.3 & 0.391 & 0.9 & 0.67 & 2163.1 & 16.0 & 2146.1 & 11.3 & 2128.4 & 15.9 & 99.17 \\
\hline $04 \mathrm{Z2}$ & 0.04 & 0.00 & 51,898 & 0.138 & 0.6 & 7.585 & 0.9 & 0.400 & 0.6 & 0.67 & 2197.6 & 10.7 & 2183.1 & 7.9 & 2167.8 & 11.7 & 99.30 \\
\hline 35 Z17 & 0.04 & 0.00 & 34,708 & 0.138 & 0.7 & 7.770 & 1.1 & 0.408 & 0.8 & 0.71 & 2205.3 & 12.6 & 2204.8 & 9.6 & 2204.1 & 14.7 & 99.97 \\
\hline 39 Z19 & 0.02 & 0.00 & 78,673 & 0.138 & 0.6 & 7.713 & 1.0 & 0.406 & 0.8 & 0.79 & 2198.4 & 10.4 & 2198.1 & 9.2 & 2197.8 & 15.3 & 99.99 \\
\hline $36 \mathrm{Z1} 18$ & 0.03 & 0.00 & 41,963 & 0.138 & 0.6 & 7.773 & 0.9 & 0.410 & 0.7 & 0.72 & 2197.6 & 9.9 & 2205.1 & 7.9 & 2213.2 & 12.4 & 100.37 \\
\hline 24 Z12 & 0.03 & 0.00 & 37,084 & 0.137 & 1.0 & 7.680 & 1.3 & 0.408 & 0.8 & 0.60 & 2183.5 & 17.3 & 2194.3 & 11.5 & 2205.8 & 15.0 & 100.53 \\
\hline \multicolumn{18}{|c|}{ Sample PARANÃ 6} \\
\hline $04 \mathrm{Z2}$ & 0.63 & 0.00 & 1144 & 0.105 & 0.6 & 2.408 & 0.9 & 0.167 & 0.7 & 0.80 & 1709.5 & 11.2 & 1244.9 & 6.6 & 994.2 & 6.4 & 79.86 \\
\hline $07 \mathrm{Z3}$ & 0.07 & 0.00 & 22,180 & 0.124 & 0.5 & 4.070 & 0.9 & 0.239 & 0.8 & 0.81 & 2008.3 & 9.1 & 1648.3 & 7.5 & 1381.0 & 9.5 & 83.78 \\
\hline $11 \mathrm{Z5}$ & 0.02 & 0.00 & 92,032 & 0.136 & 0.7 & 6.496 & 2.0 & 0.347 & 1.9 & 0.94 & 2173.4 & 11.5 & 2045.4 & 17.7 & 1920.9 & 31.7 & 93.91 \\
\hline $12 \mathrm{Z6}$ & 0.14 & 0.00 & 44,644 & 0.126 & 0.6 & 4.315 & 1.5 & 0.249 & 1.4 & 0.92 & 2039.1 & 10.1 & 1696.2 & 12.2 & 1432.8 & 17.6 & 84.47 \\
\hline $15 \mathrm{Z7}$ & 0.60 & 0.00 & 2663 & 0.129 & 0.4 & 5.019 & 1.0 & 0.283 & 0.9 & 0.89 & 2078.6 & 7.5 & 1822.5 & 8.3 & 1607.0 & 12.7 & 88.17 \\
\hline $23 \mathrm{Z11}$ & 0.01 & 0.00 & 164,312 & 0.131 & 0.5 & 6.432 & 1.2 & 0.356 & 1.0 & 0.88 & 2111.2 & 9.3 & 2036.6 & 10.2 & 1963.8 & 17.6 & 96.42 \\
\hline $28 \mathrm{Z1} 14$ & 0.95 & 0.00 & 585 & 0.112 & 0.4 & 3.349 & 0.9 & 0.218 & 0.8 & 0.84 & 1826.2 & 8.0 & 1492.7 & 6.9 & 1269.2 & 8.9 & 85.03 \\
\hline 36 Z18 & 0.24 & 0.00 & 11,122 & 0.127 & 0.5 & 4.565 & 1.1 & 0.262 & 1.0 & 0.90 & 2051.1 & 8.0 & 1743.0 & 8.9 & 1497.8 & 12.9 & 85.94 \\
\hline 39 Z19 & 0.58 & 0.00 & 2987 & 0.122 & 0.8 & 2.585 & 1.9 & 0.154 & 1.7 & 0.90 & 1979.5 & 14.3 & 1296.5 & 13.6 & 924.6 & 14.4 & 71.32 \\
\hline $40 \mathrm{Z20}$ & 0.03 & 0.00 & 77,121 & 0.129 & 0.5 & 3.782 & 2.1 & 0.212 & 2.0 & 0.97 & 2089.3 & 8.8 & 1589.0 & 16.7 & 1239.7 & 22.7 & 78.02 \\
\hline $44 \mathrm{Z22}$ & 0.02 & 0.00 & 119,003 & 0.134 & 0.4 & 6.620 & 0.9 & 0.358 & 0.8 & 0.86 & 2150.6 & 7.3 & 2062.0 & 7.7 & 1974.5 & 13.0 & 95.76 \\
\hline $47 \mathrm{Z23}$ & 0.01 & 0.00 & 148,083 & 0.110 & 0.5 & 2.917 & 1.3 & 0.192 & 1.1 & 0.91 & 1800.7 & 9.3 & 1386.2 & 9.5 & 1133.1 & 11.9 & 81.74 \\
\hline
\end{tabular}

Notes:

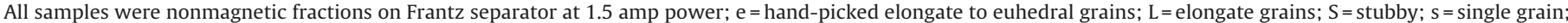
$\mathrm{m}=$ multiple grains.

First sample number = ID\# of grain. $\mathrm{p}=$ prismatic grain, $\mathrm{c}=$ clear, $\mathrm{r}=\mathrm{red}, \mathrm{h}=$ honey color.

Total $\mathrm{U}$ and $\mathrm{Pb}$ concentrations corrected for analytical blank.

Observed $206 \mathrm{~Pb} / 204 \mathrm{~Pb}$ not corrected for blank or non-radiogenic $\mathrm{Pb}$.

Radiogenic $\mathrm{Pb}$ corrected for blank and initial $\mathrm{Pb}$; U corrected for blank.

Ages given in Ma using decay constants recommended by Steiger and Jager (1977). 
Table 4

Summary of SHRIMP U-Pb zircon data.

\begin{tabular}{|c|c|c|c|c|c|c|c|c|c|c|c|c|c|c|c|}
\hline Grain spot & ${ }^{206} \mathrm{~Pb}_{\mathrm{c}}(\%)$ & $\mathrm{U}(\mathrm{ppm})$ & Th (ppm) & ${ }^{232} \mathrm{Th} /{ }^{238} \mathrm{U}$ & ${ }^{206} \mathrm{~Pb}^{*}(\mathrm{ppm})$ & ${ }^{206} \mathrm{~Pb} /{ }^{238} \mathrm{U}_{\text {age }}{ }^{\mathrm{a}}$ & ${ }^{207} \mathrm{~Pb} /{ }^{206} \mathrm{~Pb}$ age ${ }^{\mathrm{b}}$ & Discordant (\%) & ${ }^{207} \mathrm{~Pb}^{*} / 206 \mathrm{~Pb}^{*}$ & $\pm \%$ & ${ }^{207} \mathrm{~Pb}^{*} /{ }^{235} \mathrm{U}$ & $\pm \%$ & ${ }^{206} \mathrm{~Pb}^{*} / 238 \mathrm{U}$ & $\pm \%$ & Err. corr. \\
\hline \multicolumn{16}{|c|}{ Sample NAT-9A } \\
\hline 1.2 & 2.23 & 42 & 26 & 0.63 & 5.2 & $852 \pm 16$ & $674 \pm 220$ & -26 & 0.062 & 10.0 & 1.20 & 10.0 & 0.140 & 2.0 & 0.195 \\
\hline 2.2 & 1.28 & 81 & 51 & 0.65 & 10.5 & $890 \pm 14$ & $1.021 \pm 95$ & 12 & 0.073 & 4.7 & & 5.0 & 0.149 & 1.7 & 0.335 \\
\hline 4.1 & 1.59 & 117 & 57 & 0.5 & 14.3 & $841 \pm 12$ & $812 \pm 94$ & -3 & 0.066 & 4.5 & 1.271 & 4.8 & 0.139 & 1.6 & 0.329 \\
\hline 4.2 & 0.68 & 239 & 233 & 1.01 & 29.4 & $860 \pm 12$ & $815 \pm 38$ & -5 & 0.066 & 1.8 & 1.302 & 2.3 & 0.143 & 1.4 & 0.607 \\
\hline 5.1 & 0.54 & 96 & 59 & 0.63 & 12.1 & $873 \pm 15$ & $917 \pm 63$ & 5 & 0.070 & 3.1 & 1.394 & 3.5 & 0.145 & 1.8 & 0.499 \\
\hline 6.1 & 0.75 & 158 & 80 & 0.52 & 19.1 & $842 \pm 15$ & $923 \pm 88$ & 9 & 0.070 & 4.3 & 1.347 & 4.7 & 0.140 & 1.9 & 0.399 \\
\hline 6.2 & 1.99 & 146 & 95 & 0.67 & 16.8 & $795 \pm 12$ & $813 \pm 170$ & 2 & 0.066 & 8.0 & 1.199 & 8.1 & 0.131 & 1.6 & 0.193 \\
\hline 7.1 & 0.23 & 553 & 455 & 0.85 & 63.7 & $808 \pm 11$ & $842 \pm 31$ & 4 & 0.067 & 1.5 & 1.238 & 2.0 & 0.134 & 1.4 & 0.671 \\
\hline 7.2 & 1.58 & 123 & 63 & 0.52 & 11.6 & $655.2 \pm 9.8$ & $789 \pm 180$ & 17 & 0.065 & 8.6 & 0.97 & 8.7 & 0.108 & 1.6 & 0.188 \\
\hline 8.1 & 1.26 & 120 & 54 & 0.47 & 14.6 & $846 \pm 12$ & $790 \pm 99$ & -7 & 0.066 & 4.7 & 1.263 & 5.0 & 0.140 & 1.5 & 0.310 \\
\hline 8.2 & 1.81 & 119 & 61 & 0.53 & 13.6 & $792 \pm 12$ & $707 \pm 98$ & -12 & 0.063 & 4.6 & 1.131 & 4.9 & 0.130 & 1.6 & 0.325 \\
\hline 9.1 & 1.82 & 97 & 67 & 0.72 & 11.9 & $851 \pm 14$ & $839 \pm 260$ & -1 & 0.067 & 13.0 & 1.30 & 13.0 & 0.141 & 1.9 & 0.148 \\
\hline 10.1 & 1.73 & 95 & 37 & 0.4 & 11.8 & $855 \pm 15$ & $901 \pm 260$ & 5 & 0.069 & 13.0 & 1.35 & 13.0 & 0.142 & 1.9 & 0.148 \\
\hline 10.2 & 0.41 & 317 & 238 & 0.78 & 38.0 & $836 \pm 11$ & $914 \pm 38$ & 8 & 0.070 & 1.9 & 1.332 & 2.3 & 0.139 & 1.4 & 0.589 \\
\hline \multicolumn{16}{|c|}{ Sample NAT-9B } \\
\hline 1.1 & 0.82 & 108 & 38 & 0.37 & 12.8 & $827.3 \pm 7.6$ & $1063 \pm 36$ & 21 & 0.075 & 1.8 & 1.426 & 2.0 & 0.138 & 0.9 & 0.467 \\
\hline 2.1 & 0.21 & 284 & 176 & 0.64 & 34.8 & $856.7 \pm 6.7$ & $929 \pm 21$ & 8 & 0.070 & 1.0 & 1.376 & 1.3 & 0.143 & 0.8 & 0.620 \\
\hline 3.1 & 0.93 & 87 & 72 & 0.86 & 10.6 & $850.4 \pm 8.2$ & $1072 \pm 22$ & 20 & 0.075 & 1.1 & 1.474 & 1.5 & 0.142 & 1.0 & 0.663 \\
\hline 3.2 & 0.47 & 110 & 148 & 1.38 & 13.5 & $854.2 \pm 7.9$ & $941 \pm 39$ & 9 & 0.070 & 1.9 & 1.381 & 2.1 & 0.142 & 1.0 & 0.453 \\
\hline 4.1 & 1.36 & 49 & 35 & 0.75 & 5.7 & $807.4 \pm 9.2$ & $976 \pm 100$ & 17 & 0.072 & 5.1 & 1.327 & 5.3 & 0.134 & 1.2 & 0.237 \\
\hline 5.1 & 0.23 & 177 & 192 & 1.12 & 21.7 & $861 \pm 10$ & $873 \pm 30$ & 1 & 0.068 & 1.4 & 1.344 & 1.9 & 0.143 & 1.2 & 0.643 \\
\hline 6.1 & 0.72 & 443 & 325 & 0.76 & 50.6 & $800.3 \pm 6.0$ & $922 \pm 20$ & 12 & 0.070 & 1.0 & 1.278 & 1.2 & 0.133 & 0.8 & 0.626 \\
\hline 2.2 & 0.96 & 87 & 36 & 0.43 & 10.6 & $852 \pm 12$ & $1056 \pm 34$ & 18 & 0.075 & 1.7 & 1.464 & 2.3 & 0.143 & 1.5 & 0.663 \\
\hline 7.1 & 7.85 & 264 & 199 & 0.78 & 22.6 & $567 \pm 18$ & $1983 \pm 200$ & 69 & 0.122 & 11.0 & 1.67 & 11.0 & 0.100 & 2.7 & 0.235 \\
\hline 8.1 & 0.50 & 129 & 73 & 0.58 & 16.0 & $860.9 \pm 7.6$ & $1015 \pm 28$ & 14 & 0.073 & 1.4 & 1.448 & 1.7 & 0.144 & 0.9 & 0.548 \\
\hline 9.1 & 0.37 & 196 & 184 & 0.97 & 23.3 & $832.6 \pm 7.0$ & $927 \pm 20$ & 9 & 0.070 & 1.0 & 1.335 & 1.3 & 0.138 & 0.9 & 0.668 \\
\hline 10.1 & 0.40 & 361 & 177 & 0.51 & 43.0 & $834.4 \pm 6.9$ & $930 \pm 12$ & 10 & 0.070 & 0.6 & 1.34 & 1.0 & 0.139 & 0.9 & 0.814 \\
\hline 11.1 & 0.95 & 86 & 59 & 0.71 & 10.6 & $850.9 \pm 8.5$ & $1084 \pm 31$ & 20 & 0.076 & 1.6 & 1.485 & 1.9 & 0.143 & 1.0 & 0.546 \\
\hline 12.1 & 0.46 & 209 & 162 & 0.80 & 25.0 & $836.2 \pm 7.1$ & $869 \pm 36$ & 3 & 0.068 & 1.7 & 1.301 & 1.9 & 0.139 & 0.9 & 0.448 \\
\hline 13.1 & 0.65 & 135 & 120 & 0.92 & 16.0 & $827.7 \pm 7.4$ & $846 \pm 44$ & 2 & 0.067 & 2.1 & 1.271 & 2.3 & 0.137 & 0.9 & 0.404 \\
\hline 10.2 & 1.26 & 212 & 154 & 0.75 & 24.9 & $816.5 \pm 6.8$ & $887 \pm 44$ & 7 & 0.069 & 2.1 & 1.281 & 2.3 & 0.135 & 0.9 & 0.377 \\
\hline 14.1 & 0.25 & 153 & 52 & 0.35 & 19.1 & $870.2 \pm 7.7$ & $871 \pm 33$ & 0 & 0.068 & 1.6 & 1.357 & 1.8 & 0.145 & 0.9 & 0.503 \\
\hline
\end{tabular}




\begin{tabular}{|c|c|c|c|c|c|c|c|c|c|c|c|c|c|c|c|}
\hline \multicolumn{16}{|c|}{ Sample NAT-8 } \\
\hline 1.1 & 0.01 & 411 & 192 & 0.48 & 129 & $2007 \pm 20$ & $2154 \pm 6$ & 7 & 0.134 & 0.4 & 6.759 & 1.2 & 0.365 & 1.2 & 0.955 \\
\hline 2.1 & 0.02 & 369 & 233 & 0.65 & 125 & $2135 \pm 21$ & $2170 \pm 7$ & 2 & 0.135 & 0.4 & 7.334 & 1.2 & 0.393 & 1.2 & 0.950 \\
\hline 3.1 & 0.00 & 371 & 197 & 0.55 & 120 & $2060 \pm 21$ & $2154 \pm 7$ & 4 & 0.134 & 0.4 & 6.968 & 1.2 & 0.377 & 1.2 & 0.952 \\
\hline 4.1 & 0.04 & 207 & 74 & 0.37 & 67.9 & $2087 \pm 22$ & $2164 \pm 9$ & & 0.135 & 0.5 & 7.115 & 1.3 & 0.382 & 1.2 & 0.925 \\
\hline 5.1 & 0.00 & 265 & 110 & 0.43 & 87.1 & $2088 \pm 21$ & $2160 \pm 8$ & 3 & 0.135 & 0.5 & 7.100 & 1.3 & 0.382 & 1.19 & 0.936 \\
\hline 6.1 & 0.00 & 209 & 79 & 0.39 & 68.7 & $2089 \pm 24$ & $2153 \pm 22$ & 3 & 0.134 & 1.3 & 7.079 & 1.9 & 0.383 & 1.4 & 0.728 \\
\hline 7.1 & 0.00 & 520 & 175 & 0.35 & 160 & $1975 \pm 19$ & $2140 \pm 5$ & 8 & 0.133 & 0.3 & 6.580 & 1.2 & 0.358 & 1.2 & 0.966 \\
\hline 8.1 & 0.07 & 626 & 303 & 0.50 & 158 & $1660 \pm 19$ & $2031 \pm 6$ & 22 & 0.125 & 0.3 & 5.069 & 1.3 & 0.294 & 1.29 & 0.967 \\
\hline 9.1 & 0.00 & 277 & 129 & 0.48 & 88.1 & $2032 \pm 20$ & $2144 \pm 7$ & 5 & 0.133 & 0.4 & 6.820 & 1.2 & 0.371 & 1.2 & 0.942 \\
\hline \multicolumn{16}{|c|}{ Sample SVAL2 } \\
\hline 1.1 & 0.08 & 90 & 58 & 0.66 & 30.5 & $2135 \pm 27$ & $2134 \pm 13$ & -0 & 0.133 & 0.8 & 7.180 & 1.7 & 0.393 & 1.5 & 0.894 \\
\hline 2.1 & 0.00 & 213 & 72 & 0.35 & 59.7 & $1818 \pm 22$ & $2054.6 \pm 9.4$ & 13 & 0.127 & 0.5 & 5.697 & 1.5 & 0.326 & 1.4 & 0.933 \\
\hline 3.1 & 0.07 & 93 & 57 & 0.63 & 31.3 & $2124 \pm 27$ & $2151 \pm 12$ & 1 & 0.134 & 0.7 & 7.210 & 1.7 & 0.390 & 1.5 & 0.910 \\
\hline 4.1 & 0.00 & 81 & 47 & 0.60 & 26.3 & $2057 \pm 26$ & $2125 \pm 13$ & 3 & 0.132 & 0.7 & 6.840 & 1.7 & 0.376 & 1.5 & 0.900 \\
\hline 4.2 & 0.11 & 93 & 27 & 0.30 & 22.2 & $1582 \pm 26$ & $1973 \pm 15$ & 24 & 0.121 & 0.9 & 4.647 & 2.0 & 0.278 & 1.8 & 0.907 \\
\hline 5.1 & 0.69 & 156 & 81 & 0.54 & 46.2 & $1901 \pm 23$ & $2121 \pm 16$ & 11 & 0.132 & 0.9 & 6.230 & 1.7 & 0.343 & 1.4 & 0.827 \\
\hline 5.2 & 0.18 & 61 & 9 & 0.16 & 12.8 & $1412 \pm 21$ & $1922 \pm 33$ & 36 & 0.118 & 1.9 & 3.973 & 2.5 & 0.245 & 1.7 & 0.665 \\
\hline 6.1 & - & 39 & 18 & 0.48 & 12.4 & $2016 \pm 30$ & $2140 \pm 20$ & 6 & 0.133 & 1.2 & 6.740 & 2.1 & 0.367 & 1.7 & 0.834 \\
\hline 7.1 & 0.08 & 53 & 20 & 0.39 & 18.8 & $2220 \pm 30$ & $2170 \pm 37$ & -2 & 0.136 & 2.1 & 7.680 & 2.6 & 0.411 & 1.6 & 0.600 \\
\hline 7.2 & 0.09 & 41 & 27 & 0.67 & 12.6 & $1967 \pm 29$ & $2109 \pm 22$ & 7 & 0.131 & 1.2 & 6.440 & 2.1 & 0.357 & 1.7 & 0.816 \\
\hline 8.1 & 0.00 & 76 & 27 & 0.37 & 26.8 & $2229 \pm 28$ & $2158 \pm 13$ & -3 & 0.135 & 0.7 & 7.660 & 1.7 & 0.413 & 1.5 & 0.896 \\
\hline 9.1 & 0.09 & 73 & 37 & 0.53 & 24.5 & $2129 \pm 27$ & $2138 \pm 14$ & 0 & 0.133 & 0.8 & 7.180 & 1.7 & 0.391 & 1.5 & 0.881 \\
\hline 9.2 & 0.00 & 97 & 27 & 0.29 & 31.7 & $2079 \pm 26$ & $2148 \pm 12$ & 3 & 0.134 & 0.7 & 7.020 & 1.6 & 0.381 & 1.5 & 0.908 \\
\hline 10.1 & 0.00 & 31 & 12 & 0.41 & 10.6 & $2162 \pm 34$ & $2153 \pm 33$ & -0 & 0.134 & 1.9 & 7.370 & 2.7 & 0.399 & 1.8 & 0.694 \\
\hline \multicolumn{16}{|c|}{ Sample PNAC4 } \\
\hline 1.1 & 0.23 & 65 & 46 & 0.73 & 16.6 & $1682 \pm 24$ & $2032 \pm 20$ & 21 & 0.125 & 1.1 & 5.150 & 2.0 & 0.298 & 1.6 & 0.818 \\
\hline 2.1 & 0.11 & 83 & 29 & 0.37 & 25.2 & $1958 \pm 26$ & $2048 \pm 16$ & 5 & 0.126 & 0.9 & 6.180 & 1.8 & 0.355 & 1.5 & 0.865 \\
\hline 3.1 & 0.20 & 66 & 28 & 0.44 & 20.8 & $2006 \pm 28$ & $2036 \pm 20$ & 1 & 0.126 & 1.1 & 6.320 & 2.0 & 0.365 & 1.6 & 0.818 \\
\hline 4.1 & 0.16 & 72 & 30 & 0.43 & 23.6 & $2077 \pm 28$ & $2069 \pm 17$ & -0 & 0.128 & 1.0 & 6.710 & 1.8 & 0.380 & 1.5 & 0.843 \\
\hline 5.1 & 0.11 & 80 & 36 & 0.46 & 26.6 & $2099 \pm 27$ & $2043 \pm 16$ & & 0.126 & 0.9 & 6.690 & 1.7 & 0.385 & 1.5 & 0.860 \\
\hline 6.1 & 0.14 & 53 & 21 & 0.40 & 17.6 & $2106 \pm 29$ & $2054 \pm 17$ & -2 & 0.127 & 1.0 & 6.750 & 1.9 & 0.386 & 1.6 & 0.855 \\
\hline 7.1 & 0.03 & 162 & 71 & 0.45 & 46.8 & $1867 \pm 25$ & $2058 \pm 10$ & 10 & 0.127 & 0.6 & 5.887 & 1.7 & 0.336 & 1.6 & 0.935 \\
\hline 8.1 & 4.70 & 28 & 10 & 0.39 & 9.64 & $2110 \pm 40$ & $2034 \pm 160$ & -3 & 0.125 & 8.8 & 6.700 & 9.0 & 0.387 & 2.2 & 0.244 \\
\hline 9.1 & 0.18 & 50 & 16 & 0.33 & 16.1 & $2040 \pm 29$ & $2058 \pm 21$ & 1 & 0.127 & 1.2 & 6.520 & 2.0 & 0.372 & 1.6 & 0.811 \\
\hline
\end{tabular}

Notes:
Errors are 1-sigma; $\mathrm{Pb}_{\mathrm{c}}$ and $\mathrm{Pb}^{*}$ indicate the common and radiogenic portions, respectively.

Error in standard calibration was $0.39 \%$ (not included in above errors but required when comparing data from different mounts).

a Common $\mathrm{Pb}$ corrected using measured $204 \mathrm{~Pb}$.

b Common Pb corrected by assuming 206Pb/238U-207Pb/235U age-concordance. 


\section{References}

Alkmim, F.F., 2004. O que faz de um cráton um cráton? O Cráton do São Francisco e as revelações almeidianas ao delimitá-lo. In: Mantesso-Neto, V., Bartorelli, A., Carneiro, C.D.R., Brito Neves, B.B. (Org.), Geologia do Continente Sul-Americano. Evolução da Obra de Fernando Marques de Almeida. São Paulo, Beca, pp. 17-35.

Almeida, F.F.M., Hasui, Y., Brito Neves, B.B., Fuck, R.A., 1981. Brazilian structural provinces: an introduction. Earth-Science Reviews 17 (1), 1-29.

Alvarenga, C.J.S., Botelho, N.F., Campos, J.E.G., Moura, M.A., Meneses, P.R., Dardenne, M.A., Santos, R.V., 1999. Mapa Geológico da Região de Monte Alegre de Goiás, GO. Universidade de Brasília, Brasília.

Alvarenga, C.J.S., Dardenne, M.A., Botelho, N.F., Lima, O.N.B., Machado, M.A., Almeida, T., 2007. Nota Explicativa das folhas SD.23-V-C-III Monte Alegre de Goiás, SD.23V-C-V Cavalcante, SD.23-V-C-VI Nova Roma. CPRM, Brasília, 65 pp.

Araújo Filho, J.O., 2000. The Pirineus Syntaxis: an example of two Brasiliano foldthrust belts in central Brazil and its implication for the tectonic evolution of western Gondwana. Revista Brasileira de Geociências 30 (2), 144-148.

Araújo, V.A., Alves, A.C., 1979. Projeto Cana Brava-Porto Real. Goiânia, Convênio DNPM/CPRM, Final Report.

Arcanjo, S.H.S., Moura, C.A.V., 2000. Geocronologia Pb-Pb em Zircão (método de evaporação) das rochas do embasamento do setor meridional do Cinturão Araguaia-região de Paraíso do Tocantins (TO). Revista Brasileira de Geociências 30 (4), 665-670.

Assumpção, M., Heintz, M., Vauchez, A., Silva, M.E., 2006. Upper mantle anisotropy in SE and Central Brazil from SKS splitting: evidence of asthenospheric flow around a cratonic keel. Earth and Planetary Science Letters 250, 224-240.

Barbosa, O., Baptista, M.B., Dyer, R.C., Cunha, C.A.B.R., 1969. Geologia e inventário dos recursos minerais do Projeto Brasília. Rio de Janeiro, PROSPEC/DNPM, Final Report, 225 pp.

Bernasconi, A., 1983. The Archean terranes of central eastern Brazil: a review. Precambrian Research 23, 107-131.

Bizzi, L.A., Schobbenhaus, C., Vidotti, R.M., Gonçalves, J.H., 2003. Geologia Tectônica e Recursos Minerais do Brasil. CPRM Serviço Geológico do Brasil, Brasília, 674 p.

Borges, M.S., Costa, J.B.S., Hasui, Y., 1998. Litoestratigrafia da seqüência metavulcanosedimentar de Dianópolis-Almas, sudeste de Tocantins. Geociências (UNESP) 17 (1), 9-59.

Borges, M.S., Costa, J.B.S., Hasui, Y., 1999. A estruturação da seqüência metavulcanosedimentar de Almas-Dianópolis, sudeste de Tocantins. Anais da Academia Brasileira de Ciências 71 (4), 697-716.

Botelho, N.F., 1992. Les ensembles granitiques subalcalins à peralumineux minéralisés Cu, Sn et de La sous-province Paranã, état de Goiás, Brésil, vol. VI. Université Paris (Tèse de Doctorat) 343p.

Botelho, N.F., Alvarenga, C.J.S., Dardenne, M.A., Campos, J.E.G., 1998. Mapa Geológico da Região de Cavalcante, GO. Universidade de Brasília, Brasília.

Botelho, N.F., Alvarenga, C.J.S., Meneses, P.R., D’el-Rey Silva, L.J.H., 1995. Mapa Geológico da Região de Teresina de Goiás, GO. Universidade de Brasília, Brasília.

Botelho, N.F., Alvarenga, C.J.S., Meneses, P.R., D’el-Rey Silva, L.J.H., 1999. Suite Aurumina: Uma suíte de granitos paleoproterozóicos, peraluminosos e sin-tectônicos na Faixa Brasília. Simpósio de Geologia do Centro Oeste, vol. 7. SBG, Anais, Brasília, pp. 17.

Botelho, N.F. Fuck, R.A., Dantas, E.L., Laux, J.L., Junges, S.L., 2006. The Paleoproterozoic peraluminous Aurumina granite suíte, Goiás and Tocantins: whole rock geochemistry and Sm-Nd isotopic constraints. In: The Paleoproterozoic Record of the São Francisco Craton, Brazil, IGCP 509, Brazil, September 9-21.

Brito Neves, B.B., 2011. The Paleproterozoic in the South American Continent: diversity in the geological time. Journal of South American Earth Sciences 32, 1-20.

Brito Neves, B.B., Fuck, R.A., Cordani, U.G., Thomaz Filho, A., 1984. Influence of basement structures in the evolution of the major sedimentary basins of Brazil. Journal of Geodynamics 1 (3-5), 495-510.

Brito Neves, B.B., Santos, E.J., Van Schmus, W.R., 2000. Tectonic history of the Borborema Province, northeastern Brazil. In: Cordani, U.G., Milani, E.J., Thomaz Filho, A., Campos, D.A. (Eds.), Tectonic Evolution of South America. Rio de Janeiro, 31st International Geological Congress. , pp. 151-182.

Campos, J.E.G., Botelho, N.F., Alvarenga, C.J.S., Meneses, P.R., Moura, M.A., Dardenne, M.A., Nogueira, C., Souza, V.S., 2001. Mapa Geológico da Região de Arraias, TO. Universidade de Brasília, Brasília.

Campos, J.E.G., Dantas, E.L., Roig, H.L., Botelho, N.F., Almeida, T., Souza, V.S., Borges, W.R., 2010. Mapa Geológico de Paranã-São Salvador, Tocantins. Universidade de Brasília, Brasília.

Campos Neto, M.C., 2000. Orogenic systems from southwestern Gondwana: an approach to Brasiliano-Pan African cycle and orogenic collage in southeastern Brazil. In: Cordani, U.G., Milani, E.J., Thomaz Filho, A., Campos, D.A. (Eds.), Tectonic Evolution of South America. Rio de Janeiro, 31st International Geological Congress. , pp. 335-365

Campos Neto, M.C., Basei, M.A.S., Janasi, V.A., Moraes, R., 2011. Orogen migration and tectonic setting of the Andrelândia Nappe system: an Ediacaran western Gondwana collage, south of São Francisco craton. Journal of South American Earth Sciences 32, 393-406.

Chaves, C.L., Gorayeb, P.S.S., Moura, C.A.V., 2003. A granitogênese paleoproterozóica no setor setentrional da Província Tocantins: idades modelo (TDM) e evaporação de Pb em zircão. In: Simpósio de Geologia da Amazônia, Manaus. Anais 1, pp. 47-51.

Compston, W., Williams, I.S., Kirschvink, J.L., Zhang, Z., Ma, G., 1992. Zircon U-Pb ages for the early Cambrian timescale. Journal Geological Society London 149, $171-184$.

Condie, K.C. (Ed.), 1994. Archean Crustal Evolution. Elsevier, Amsterdam, 528 pp.
Condie, K.C., 2002. Breakup of a Paleoproterozoic supercontinent. Gondwana Research 5, 41-43.

Condie, K.C., Aster, R.C., 2010. Episodic zircon age spectra of orogenic granitoids: the supercontinent connection and continental growth. Precambrian Research 180 $227-236$

Condie, K.C., Des Marais, D.J., Abbott, D., 2000. Precambrian superplumes and supercontinents: a Record in Black shales, carbon isotopes, and paleoclimates? Precambrian Research 106, 239-260.

Cordani, U.G., Brito Neves, B.B., Fuck, R.A., Porto, R., Thomaz Filho, A., Cunha, F.M.B. 1984. Estudo preliminar de integração do Pré-Cambriano com os eventos tectônicos das bacias sedimentares brasileiras. Ciência-Técnica-Petróleo, Seção Exploração de Petróleo, pp. 15.

Cordani, U.G., Brito Neves, B.B.B., D'Agrella, M.S., 2003a. From Rodinia to Gondwana: a review of the available evidence from South America. Gondwana Research 6 (2), 275-284

Cordani, U.G., Brito Neves, B.B.B., D'Agrella, M.S., Trindade, R.I.F., 2003b. Tearing up Rodinia: the Neoproterozoic paleogeography of South American cratonic fragments. Terra Nova 15 (5), 343-349.

Cordani, U.G., Sato, K., 1999. Crustal evolution of the South American Platform, based on Nd isotopic systematics on granitoids rocks. Episodes 22 (3), 167-173.

Cordani, U.G., Sato, K., Teixeira, W., Tassinari, C.C.G., Basei, M.A.S., 2000. Crustal evoltion of the South American platform. In: Cordani, U.G., Milani, E.J., Thomaz Filho, A., Campos, D.A. (Eds.), Tectonic Evolution of South America. Rio de Janeiro, 31st International Geological Congress. , pp. 19-40.

Correia Filho, F.C.L., Sá, A.M., 1980. Projeto Natividade. Goiânia, Convênio DNPM/CPRM, Final Report, 120 pp.

Costa, J.B.S., 1985. Aspectos lito-estruturais e evolução crustal da região centro-norte de Goiás. Universidade Federal do Pará, Tese de Doutorado, Belém, 209 pp.

Costa, L.A.M., Portela, A.C., Nilson, A.A., Vale, C.R.O., Marchetto, C.L.M., Santos, E.L., Meneguesso, G., Inda, H.A.V., Sterna, R., Marchetto, M., Baptista, M.B., Fratin, O. Mosmann, R., Oliveira, T.F.D., Silva, W.G., 1976. Projeto Leste do Tocantins/Oeste do São Francisco. Rio de Janeiro, Convênio DNPM/CPRM/PROSPEC, Final Report, 200 pp.

Cruz, E.L.C.C., 2001. A gênese e o contexto tectônico da mina Córrego Paiol: um depósito de ouro hospedado em anfibolito do embasamento da Faixa de Dobramentos Brasília. Tese Doutorado, Instituto de Geociências, Universidade Brasília, Brasília, 183 pp.

Cruz, E.L.C.C., Kuyumjian, R.M., 1996. Chemical characterization of metabasalts and granitoids from the Almas-Dianópolis granite-greenstone terrane, central Brazil. In: SBG, Symposium on Archaean Terranes of the South American Platform, vol. 1, pp. 53-54, Extended Abstracts.

Cruz, E.L.C.C., Kuyumjian, R.M., 1998. The geology and tectonic evolution of the Tocantins granite-greenstone terrane: Almas-Dianópolis region, Tocantins State, central Brazil. Revista Brasileira de Geociências 28 (2), 173-182.

Cruz, E.L.C.C., Kuyumjian, R.M., 1999. Mineralizações auríferas filoneanas do terreno granito-greenstone do Tocantins. Revista Brasileira de Geociências 29 (3) $291-298$.

Cruz, E.L.C.C., Kuyumjian, R.M., Boaventura, G.R., 2003. Low-K calc-alkaline granitic series of southeastern Tocantins State: chemical evidence for two sources for the granite-gneissic complexes in the Paleoproterozoic Almas-Dianópolis Terrane. Revista Brasileira de Geociências 33 (2), 125-136.

Dardenne, M.A., 2000. The Brasília fold belt. In: Cordani, U.G., Milani, E.J., Thomaz Filho, A., Campos, D.A. (Eds.), Tectonic Evolution of South America. Rio de Janeiro, 31st International Geological Congress. , pp. 231-263.

Dardenne, M.A., Giustina, M.E.S.D., Sabóia, A.M., Bogossian, J., 2009. Datação geocronológica U-Pb da sequência vulcânica de Almas, Tocantins. In: SBG, Simp. Geol. Centro-Oeste, 11, Anais, 1 CD-Rom.

Della Giustina, M.E.S., Oliveira, C.G., Pimentel, M.M., Melo, L.V., Fuck, R.A., Dantas E.L., Bühn, B.M., 2009. U-Pb and Sm-Nd constraints on the nature and evolution of Paleoproterozoic juvenile crust in the Tocantins Province, central Brazil. Geological Society, London Special Publication 323, 255-269.

DePaolo, D.J., 1981. A neodymium and strontium isotopic study of the Mesozoic calc-alkaline granitic batholiths of the Sierra Nevada and Peninsular ranges, California. Journal of Geophysical Research 86, 10470-10488.

Evans, D.A.D., Mitchell, R.N., 2011. Assembly and breakup of the core of Paleoproterozoic-Mesoproterozoic supercontinent Nuna. Geology 39, 443-446.

Fernandes, P.E.C.A., Montes, M.L., Braz, E.R.C., Montes, A.S.L., Silva, L.L., Oliveira, F.L.L. Ghignone, J.I., Siga Jr., O., Castro, H.E.F., 1982. Folha SD-23 Brasília - Geologia. Brasília, Ministério de Minas e Energia, Projeto RADAMBRASIL., pp. 25-204.

Fetter, A.H., Van Schmus, W.R., Santos, T.J.S., Arthaud, M.H., Nogueira Neto, J.A., 2000. U-Pb and Sm-Nd geochronological constraints on the crustal evolution and basement architecture of Ceará State, NW Borborema Province, NE Brazil: implications for the existence of the Paleoproterozoic supercontinent 'Atlantica'. Revista Brasileira de Geociências 30, 102-106.

Frasca, A.A.S., Lima, H.A.F., Moraes, L.L., Ribeiro, P.S.E., 2010. Geologia e recursos minerais da Folha Gurupi SC.22-Z-D, escala 1:250.000. CPRM Serviço Geológico do Brasil, Goiânia, 180 pp.

Fuck, R.A., Brito Neves, B.B., Schobbenhaus, C., 2008. Rodinia descendants in South America. Precambrian Research 160, 108-126.

Fuck, R.A., Dantas, E.L., Pimentel, M.M., Junges, S.L., Moraes, R., 2001. Nd isotopes $\mathrm{U}-\mathrm{Pb}$ single grain and SHRIMP zircon ages from basement rocks of the Tocantins Province. In: III South American Symposium on Isotope Geology, 2001, Pucon. Proceedings, Extended Abstract Volume (CD ROM), Santiago: Servicio Nacional de Geologia y Mineria 1, pp. 141-144.

Fuck, R.A., Dantas, E.L., Vidotti, R.M., Roig, H.L., Almeida, T., 2011. Transbrasiliano lineament: a review and new data from airborne surveys and SRTM data. In: 
Gondwana 14 Reuniting Gondwana: the East meets the West, Búzios. Abstracts. Rio de Janeiro: SBG, p.117.

Fuck, R.A., Marini, O.J., 1979. O Grupo Araxá e unidades homotaxiais. In: Simpósio sobre o Cráton do São Francisco e suas Faixas Marginais, 1981, Salvador. Anais. SGM/Sociedade Brasileira de Geologia, Salvador, pp. 118-130.

Fuck, R.A., Marini, O.J., Dardenne, M.A., Figueiredo, A.N., 1988. Coberturas metassedimentares do Proterozóico Médio: Os grupos Araí e Paranoá na região de Niquelândia-Colinas, Goiás. Revista Brasileira de Geoiências 18 (1), 54-62.

Fuck, R.A., Pimentel, M.M., D’el Rey Silva, L.J.H., 1994. Compartimentação tectônica na porção oriental da Província Tocantins. In: 38 Congresso Brasileiro de Geologia, 1994, Balneário Camboriú. Boletim de Resumos Expandidos. Florianópolis: Sociedade Brasileira de Geologia, vol. 1, pp. 215-216.

Gasquet, D., Barbey, P., Adou, M., Paquette, J.L., 2003. Structure, Sm-Nd isotope geochemistry and zircon $\mathrm{U}-\mathrm{Pb}$ geochronology of the granitoids of the Dabakala area (Côte d'Ivoire): evidence for a $2.3 \mathrm{Ga}$ crustal growth event in the Paleoproterozoic of West Africa? Precambrian Research 127, 329-354.

Gioia, S.M.C.L., Pimentel, M.M., 2000. The Sm-Nd isotopic method in the geochronology laboratory of the University of Brasília. Anais da Academia Brasileira de Ciências 72 (2), 219-245.

Gorayeb, P.S.S., Chaves, C.L., Moura, C.A.V., da Silva, L.L.R., 2013. Neoproterozoic granites of the Lajeado intrusive suite, north-center Brazil: a late Ediacaran remelting of a Paleoproterozoic crust. Journal of South American Earth Sciences $45,278-292$

Gorayeb, P.S.S., Costa, J.B.S., Lemos, L.R., Gama Junior, T., Bemerguy, R.L., Hasui, Y., 1988. O Pré-Cambriano da região de Natividade, TO. Revista Brasileira de Geociências 18 (4), 391-397.

Gorayeb, P.S.S., Moura, C.A.V., Barros, G.R., 2000. Pb-Pb zircon ages of the Porto Nacional high-grade metamorphic terrain, northern portion of the Goiás Massif, central Brazil. Revista Brasileira de Geociências 30 (1), 215-224.

Hartlaub, R.P., Heaman, L.M., Chako, T., Ashton, K.E., 2007. Circa 2.3 Ga magmatism of the Arrowsmith Orogeny, Uranium City Region, Western Churchill Craton, Canada. Journal of Geology 115, 181-195

Hasui, Y., Costa, J.B.S., Saad, A.R., Campanha, V.A., 1990. O Grupo Natividade e sua correlação com o Grupo Bambuí. Geociências (UNESP), São Paulo, v. Especial., pp. 299-316.

Hasui, Y., Costa, J.B.S., Haralyi, N.L.E., 1994. Estrutura em Quilha Brasil Central, uma feição fundamental na geologia de Goiás e Tocantins. Geociências 13 (2), 463-497.

Hasui, Y., Tassinari, C.C.G., Siga Jr., O., Teixeira, W., Almeida, F.F.M., Kawashita, K., 1980. Datações Rb-Sr e K-Ar do centro-norte do Brasil e seu significado geológico-tectônico. 31 Congresso Brasileiro de Geologia, Anais, vol. 5., pp. 2659-2676.

Jackson, S.E., Pearson, N.J., Griffin, W.L., Belousova, E.A., 2004. The application of laser ablation $=$ inductively coupled plasma-mass spectrometry to in situ U-Pb zircon geochronology. Chemical Geology 211, 47-69.

Jost, H., Chemale Jr., F., Dussin, I.A., Martins, R., 2010. A U-Pb zircon Paleoproterozoic age for the metasedimentary host rocks and gold mineralization of the Crixás greenstone belt, Goiás, central Brazil. Ore Geology Reviews 37, 127-139.

Krogh, T.E., 1973. A low-contamination method for hydrothermal decomposition of zircon and extraction of $\mathrm{U}$ and $\mathrm{Pb}$ for isotope age determinations. Geochimica et Cosmochimica Acta 37, 485-494

Kuyumjian, R.M., Araújo Filho, J.O., 2005. Depósitos e ocorrências de ouro no terreno arqueano-paleoproterozóico de Almas-Dianópolis (TO): evidências da importância metalogenética do evento Brasiliano. Revista Brasileira de Geociências 35 (4), 611-614.

Kuyumjian, R.M., Cruz, E.L.C.C., Araújo Filho, J.O., Moura, M.A., Guimarães, E.M., Pereira, K.M.S., 2012. Geologia e ocorrências de ouro do Terreno Granito-Greenstone do Tocantins, TO: síntese do conhecimento e parâmetros para exploração mineral. Revista Brasileira de Geociências 42 (1), 213-228.

Ledru, P., Cocherie, A., Barbosa, J.S.F., Johan, V., Onstott, T., 1994. Ages du métamorphisme granulitique dans le craton du São Francisco (Brésil). Implications sur La nature de l'orogène transamazonien, vol. 312 (série II). Comptes Rendues Académie Sciences, Paris, pp. 251-257.

Ludwig, K.R., 1993. ISOPLOT - A Plotting and Regression Program for Radiogenic Isotope Data, Version 2.70. U.S. Geological Survey Open/File Report 91-445, 42 pp.

Ludwig, K.R., 2001a. Squid 1.02. A User's Manual. BGC Special Publ. 2. Berkeley, 19

Ludwig, K.R., 2001b. User?s manual for Isoplot/Ex v. 2.47. A geochronological toolkit for Microsoft Excel. BGC Special Publ. 1a, Berkeley, 55 pp.

Ludwig, K.R., 2003. Isoplot 3.00: A Geochronological Toolkit for Microsoft Excel. Berkeley Geochronological Center, Special Publication 4, 70p.

Marini, O.J., Fuck, R.A., Danni, J.C.M., Dardenne, M.A., Loguercio, S.O.C., Ramalho, R., Coutinho, M.G., 1984. As Faixas de Dobramentos Brasilia, Uruaçu e Paraguai-Araguaia e o Maciço de Goiás. In: Schobbenhaus, C., Campos, D.A., Derze, G.R., Asmus, H.E. (Org.), Geologia do Brasil. Brasília, DNPM, pp. 251-303.

Marini, OJ., Fuck, R.A. Dardenne, M.A. Danni, J.C.M. 1984. Província Tocantins, Setores Central e Sudeste. In: Almeida, F.F.M., Hasui, Y. (Org.), O Pré-Cambriano do Brasil. São Paulo, Edgard Blücher, pp. 205-264.

Marques, G.C., 2009. Geologia dos grupos Araí e Serra da Mesa e seu embasamento no sul de Tocantins. Universidade de Brasília, Brasília (MSc Dissertation), 120 p.
Paces, J.B., Miller, J.D., 1989. Precise U-Pb ages of Duluth Complex and related mafic intrusions, northeastern Minnesota: geochronological insights to physical, petrogenic, paleomagnetic and tectonomagmatic processes associated with the $1.1 \mathrm{Ga}$ midcontinent rift system. Journal of Geophysical Research 98B, $13997-14013$

Padilha, J.L., 1984. Prospecção de ouro na região nordeste de Goiás-Projeto Pindorama-Docegeo. In: SBG, Encontro Regional do Ouro de Goiás, I, Anais., pp. 78-95.

Pereira, R.S., Fuck, R.A., 2005. Archean nuclei and the distribution of kimberlite and related rocks in the São Francisco Craton, Brazil. Revista Brasileira de Geociências 35, 93-104.

Pimentel, M.M., Botelho, N.F., 2001. Sr and Nd isotopic characteristics of 1.77-1.58 Ga rift-related granites and volcanics of the Goiás Tin Province, central Brazil. Anais da Academia Brasileira de Ciências 73 (2), 263-276.

Pimentel, M.M., Fuck, R.A., 1992. Neoproterozoic crustal accretion in central Brazil. Geology 20 (4), 375-379.

Pimentel, M.M., Fuck, R.A., Botelho, N.F., 1999. Granites and the geodynamic history of the Neoproterozoic Brasilia Belt: a review. Lithos 46, 463-483.

Pimentel, M.M., Fuck, R.A., Jost, H., Ferreira Filho, C.F., Araújo, S.M., 2000. In: Cordani, U.G., Milani, E.J., Thomaz Filho, A., Campos, D.A. (Eds.), Tectonic Evolution of South America. Rio de Janeiro, 31st International Geological Congress. , pp. $151-182$

Pimentel, M.M., Heaman, L., Fuck, R.A., Marini, O.J., 1991. U-Pb zircon geochronology of Precambrian tin-bearing continental-type acid magmatism in central Brazil. Precambrian Research 52, 321-335.

Pimentel, M.M., Jost, H., Fuck, R.A., 2004. O embasamento da Faixa Brasília e o Arco Magmático de Goiás. In: Mantesso Neto, V., Bartorelli, A., Carneiro, C.D.R., Brito Neves, B.B. (Org.), Geologia do Continente Sul-Americano: Evolução da Obra de Fernando Flávio Marques de Almeida. São Paulo, Beca Produções Culturais Ltda., pp. 355-368.

Pimentel, M.M., Whitehouse, M.J., Viana, M.G., Fuck, R.A., Machado, N., 1997. The Mara Rosa Arc in the Tocantins Province: further evidence for Neoproterozoic crustal accretion in central Brazil. Precambrian Research 81, 299-310.

Reddy, S.M., Evans, D.A.D., 2009. Palaeoproterozoic supercontinents and global evolution: correlations from core to atmosphere. Geological Society, London Special Publications 323, 1-26.

Rogers, J.J.W., Santosh, M., 2002. Configuration of Columbia, a Mesoproterozoic supercontinent. Gondwana Research 5, 5-22.

Sá,J.M., Bertrand, J.M., Leterrier, J., 1991. Évolution geodynamique et geochronologie $\mathrm{U}-\mathrm{Pb}, \mathrm{Rb}-\mathrm{Sr}$ et $\mathrm{K}-\mathrm{Ar}$ de la Ceinture Plissee d'Orós, NE du Brésil. Compte-Rendu de l'Academie de Sciences de Paris 313, 213-237.

Santos, T.J.S., Fetter, A.H., Van Schmus, W.R., Hackspacher, P.C., 2009. Evidence for 2.35-2.30 Ga juvenile crustal growth in the northwest Borborema Province, NE Brazil. In: Reddy, S.M., Mazunder, R., Evans, D.A.D., Collins, A.S. (Eds.), Palaeoproterozoic Supercontinents and Global Evolution. Geological Society, London, Special Publications, vol. 323, pp. 271-281.

Schobbenhaus, C., Ribeiro, C.L., Oliva, L.A., Takanohashi, J.T., Lindenmayer, A.G., Vasconcelos, J.C., Orlandi, V., 1975. Carta Geológica do Brasil ao Milionésimo, Folha Goiás (SD-22). DNPM, Brasília.

Soares, J.E.P., Berrocal, J.A., Fuck, R.A., Mooney, W.D., Ventura, D.B.R., 2006. Seismic characteristics of central Brazil crust and upper mantle: a deep seismic refraction study. Journal of Geophysical Research 111, B12302, http://dx.doi.org/10.1029/2005JB003769.

Sparrenberger, I., Tassinari, C.C.G., 1999. Subprovíncia do Rio Paranã (GO): um exemplo de aplicação dos métodos de datação U-Pb e Pb-Pb em cassiterita. Revista Brasileira de geociências 29, 405-414.

Stacey, J.S., Kramers, J.D., 1975. Approximation of terrestrial lead isotope evolution by a two stage model. Earth and Planetary Science Letters 26, 2027-2221.

Steiger, R.H., Jager, E., 1977. Subcommission on Geochronology- convention and use of decay constants in geochronology and cosmochronology. Earth and Planetary Science Letters 36, 359-362.

Thomsen, F.P.R., Kuyumjian, R.M., 1994. Caracterização geoquímica preliminar das rochas granitóides da região de Conceição, TO. In: SBG, Simpósio de Geologia do Centro-Oeste, 4, Goiânia, Resumos., pp. 26-27.

Trompette, R., 1994. Geology of Western Gondwana. Balkema, Rotterdam, 350 pp.

Trouw, R.A.J., Heilbron, M., Ribeiro, A., Paciullo, F., Valeriano, C.M., Almeida, J.C.H., Tupinambá, M., Andreis, R.R., 2000. The central segmento f the Ribeira Belt. In: Cordani, U.G., Milani, E.J., Thomaz Filho, A., Campos, D.A. (Eds.), Tectonic Evolution of South America. Rio de Janeiro, 31st International Geological Congress. pp. 287-310.

Unrug, R., 1996. The assembly of Gondwanaland. Episodes 19, 11-20.

Valeriano, C.M., Dardenne, M.A., Fonseca, M.A., Simões, L.S.A., Seer, H.J. 2004 A evolução tectônica da Faixa Brasília. In: Mantesso Neto, V., Bartorelli, A. Carneiro, C.D.R., Brito Neves, B.B. (Org.), Geologia do Continente Sul-Americano - Evolução da obra de Fernando Flávio Marques de Almeida. São Paulo, Beca, pp. 575-592.

Valeriano, C.M., Pimentel, M.M., Heilbron, M., Almeida, J.C.H., Trouw, R.A.J., 2008. Tectonic evolution of the Brasilia Belt, central Brazil, and early assembly of Gondwana. Geological Society, London Special Publication 294 p.197-p.210.

Vasquez, M.L., Macambira, M.J.B., Armstrong, R.A., 2008. Zircon geochronology of granitoids from western Bacajá domain, southeastern Amazonian craton, Brazil: Neoarchean to Orosirian evolution. Precambrian Research 161, 297-302. 
Viana, M.G., Pimentel, M.M., Whitehouse, M.J., Fuck, R.A., Machado, N., 1995. 0 Arco Magmático de Mara Rosa, Goiás: geoquimica e geocronologica e suas implicações regionais. Revista Brasileira de Geociências 25 (2), 111-123.

Williams, I.S., Claesson, S., 1987. Isotopic evidence for the Precambrian provenance and Caledonian metamorphism of high-grade paragneisses of the Seve Nappes,
Scandinavian Caledonides. II. Ion microprobe zircon U-Th-Pb. Contributions to Mineralogy and Petrology 97, 205-217.

Zhao, G., Sun, M., Wilde, S.A., Li, S., Zhang, J., 2006. Some key issues in reconstructing

Proterozoic continents. Journal of Asian Earth Sciences 28, 3-19. 